\title{
Black NePhrite Jade from GuaNGXI, SOUTHERN CHINA
}

Qian Zhong, Zongting Liao, Lijian Qi, and Zhengyu Zhou

Twelve black nephrite samples collected from the Guangxi region of southern China were investigated by standard gemological testing, polarized microscopy, scanning electron microscopy, and electron microprobe analysis, as well as infrared, Raman, and ultraviolet/visible/near-infrared spectroscopy. Originating from Ca-skarn contact metasomatism between limestone bearing siliceous rock and diabase intrusions, black nephrite from Guangxi consists mainly of actinolite or ferro-actinolite and minor stilpnomelane, andradite, apatite, epidote, quartz, diopside, pyrrhotite, and pyrite. Its high refractive index (1.625-1.650) and specific gravity (3.015-3.405), as well as its black color in natural light for plate samples and greenish yellow/brownish yellow or pale green/yellowish green/green color in transmitted light for thin-section samples, are primarily attributable to a high iron content: 11.67-25.75 wt. \% Fe oxides and a $\mathrm{Mg} /\left(\mathrm{Mg}+\mathrm{Fe}^{2+}\right)$ ratio of 0.765-0.343. Mid- and near-infrared spectra and Raman spectra are characterized by four vibration bands corresponding to hydroxyl groups coordinated to three cations in $M_{1}$ and $M_{3}$ positions for $\left(\mathrm{M}_{1} \mathrm{M}_{1} \mathrm{M}_{3}\right) \mathrm{OH}$ combinations $(\mathrm{Mg})_{3} \mathrm{OH},\left(\mathrm{Mg}_{2} \mathrm{Fe}^{2+}\right) \mathrm{OH},\left(\mathrm{MgFe}^{2+}{ }_{2}\right) \mathrm{OH}$, and $\left(\mathrm{Fe}^{2+}\right)_{3} \mathrm{OH}$. Their relative intensities further indicate different iron contents and isomorphous substitution of $\mathrm{Fe}^{2+}$ for $\mathrm{Mg}^{2+}$ ions.

$\mathrm{N}$ ephrite is an essentially monomineralic rock composed primarily of tremolite-actinolite $\left[\mathrm{Ca}_{2}(\mathrm{Mg}, \mathrm{Fe})_{5} \mathrm{Si}_{8} \mathrm{O}_{22}(\mathrm{OH})_{2}\right]$ amphiboles in a felted microcrystalline habit (Leake et al., 1997), making it greasy, tough, and easy to carve. Nephrite mainly forms in two settings (Harlow and Sorenson, 2005; Harlow et al., 2014). The first is dolomite replacement by silicic fluids commonly associated with granitic plutonism (i.e., D-type). Important deposits occur at Xinjiang, China (Liu et al., 2011a, 2015); Chuncheon, South Korea (Yui and Kwon, 2002); and Cowell, South Australia (Flint and Dubowski, 1990). The other type of setting is serpentinite replacement by Ca-metasomatism at contacts with more silicic rock (i.e., S-type). Related deposits include Siberia, Russia (Prokhor, 1991); South Island, New Zealand (Wilkins et al., 2003); British Columbia, Canada (Leaming, 1998); and Fengtien, Taiwan (Yui et al., 2014). Nephrite found in the southern Chinese region of Guizhou forms in a different setting, within the metasomatic zone between diabase and limestone bearing siliceous rock (Yang, 2013).

See end of article for About the Authors and Acknowledgments.

Gems \& Gemology, Vol. 55, No. 2, pp. 198-215,

http://dx.doi.org/10.5741/GEMS.55.2.198

(C) 2019 Gemological Institute of America
In 2011, a new nephrite deposit was discovered in southern China at Yantan Town, Dahua County, in the Guangxi Zhuang Autonomous Region (Li et al., 2011). The Guangxi deposit is separated from the Guizhou deposit by the Hongshui River. Nephrite from Guangxi comes in a wide variety of colors such as white, green, brown, and black, and some varieties exhibit either a banded structure or a dendritic pattern (Wang et al., 2012; Yin et al., 2014). Among them, the nephrite with a homogeneous, pure black color reminiscent of Chinese calligraphic ink is the most prized by jade carvers and traders (figure 1). Several scholars have studied the mineralogy, spectroscopy, and genesis of black nephrite from Guangxi (Wang et al., 2014; Mo and Mao, 2016; Peng et al., 2017). The results suggest that it consists mainly of actinolite or ferro-actinolite and features a high iron content. Wang et al. (2014) proposed that the Guangxi deposit is a skarn-type occurrence and conducted preliminary analysis of its formation process. But few studies have discussed how high iron content influences its gemological properties or vibrational spectra. Moreover, detailed data and systematic research on its formation mechanism are still limited.

This study employed standard gemological testing, polarized microscopy, scanning electron microscopy, electron microprobe analysis, infrared spectroscopy, Raman spectroscopy, and ultraviolet/ 


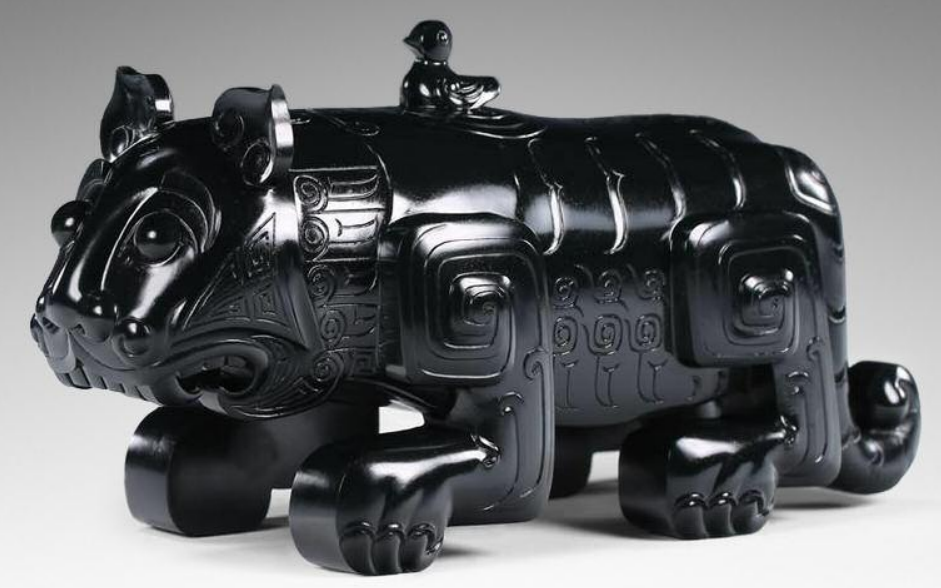

Figure 1. A zun (Chinese ritual wine vessel) ornately carved from Guangxi black nephrite in the form of a tiger squatting on all fours with a bird on its back. Photo courtesy of Hongwei $M a$.

visible/near-infrared spectroscopy to investigate the gemological properties, petrographic features, microstructures, chemical compositions, and vibrational spectra of black nephrite from Guangxi. The results demonstrate relationships between iron content and gemological properties as well as vibrational spectra. Additionally, the authors propose evidence for its deposit type and discuss the source rocks involved in its formation. This study will help in the identification of black nephrite from Guangxi and provide a basis for further research on the formation mechanism of nephrite from southern China.

\section{GEOLOGICAL SETTING}

Located in the intersection zone of the Tethys Tectonic Domain and the Circum-Pacific Tectonic Region, the Guangxi black nephrite deposit is between the southeast margin of the Yangtze Craton and the South China Caledonian Fold Belt, and adjacent to the Sanjiang Orogenic Belt in the southwest (Bureau of Geology and Mineral Resources of Guangxi Zhuang Autonomous Region, 1985; figure 2). According to the geologic map from the Chinese National Geological Archives (figure 3), the strata exposed here consist mainly of marine carbonate

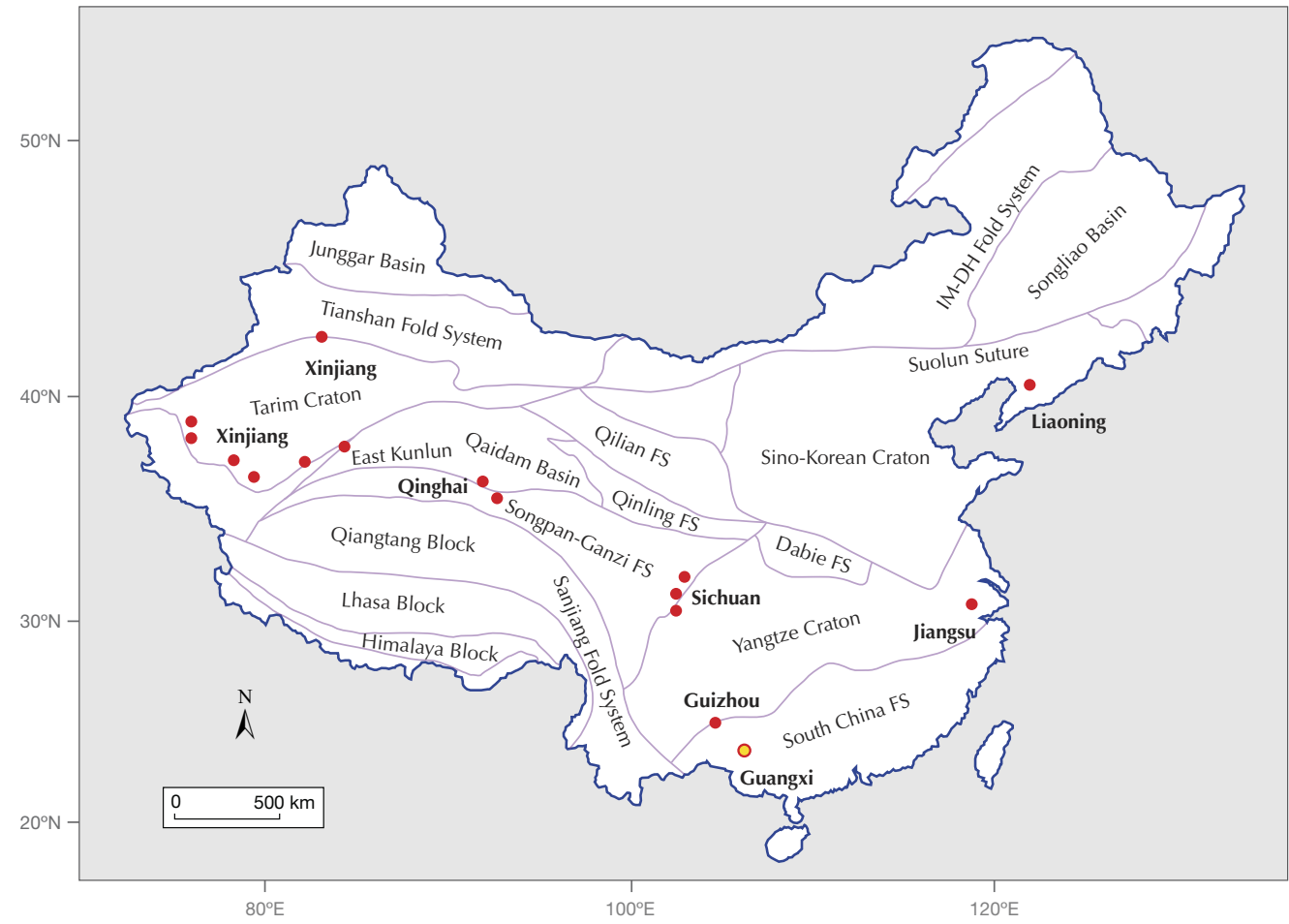

Figure 2. China is famous for its large-scale and high-quality nephrite production, as well as its long history of exquisite carving. Locations of the main deposits in Guangxi (this study), Guizhou (Yang, 2013), Xinjiang (Tang et al., 1994), Qinghai (Wang et al., 2007), Liaoning (Wang et al., 2002), Sichuan (Wang, 1993; Lu, 2005; Jin et al., 2014), and Jiangsu (He et al., 2002) are shown on this tectonic map of China (after Chen et al., 2010). 

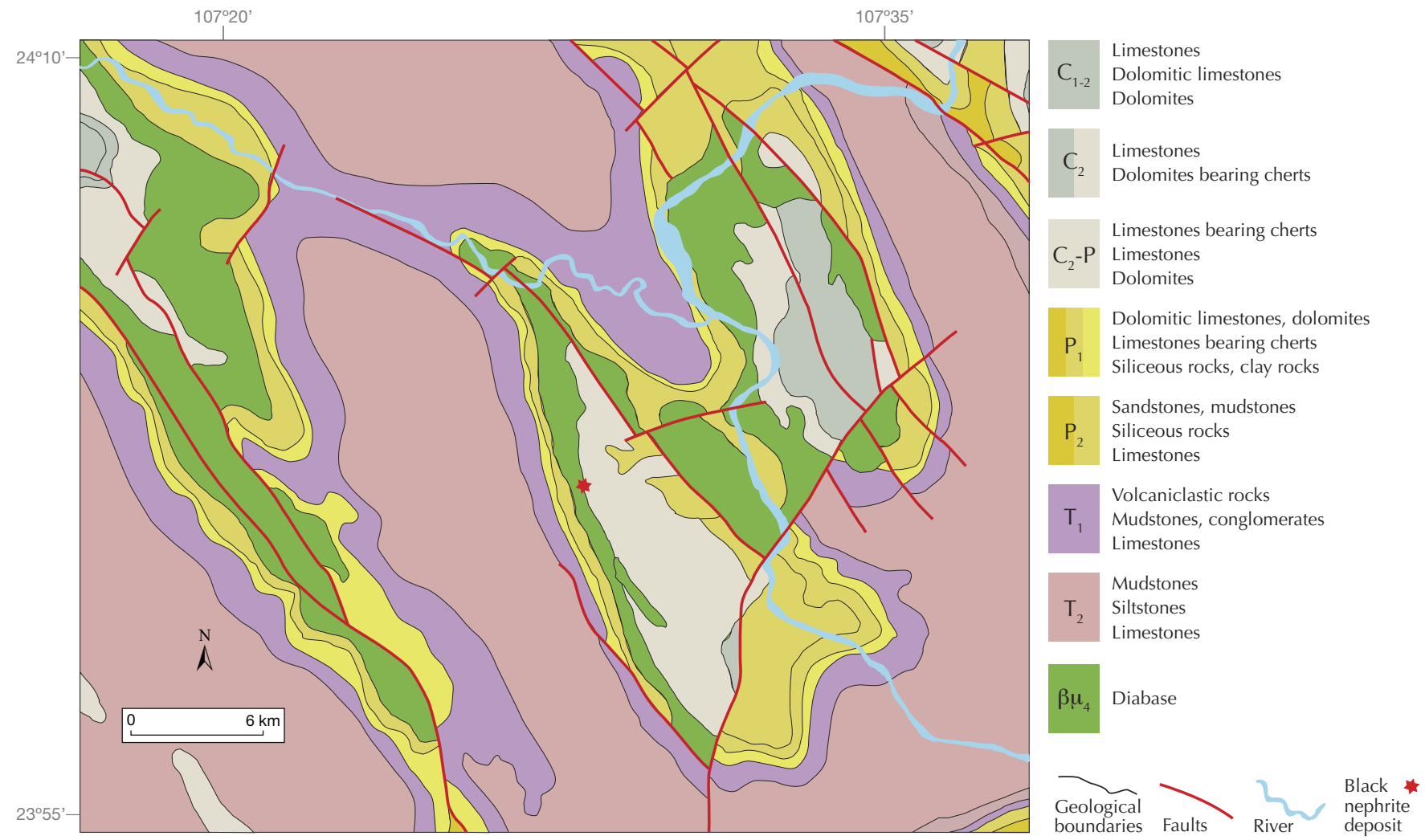

Figure 3. Regional geologic map of the Guangxi black nephrite primary deposit. The deposit occurs at the contact zone between marine carbonate rock bearing chert/siliceous rock/clay rock deposited from the Upper Carboniferous to Lower Permian periods $\left(C_{2}-P_{1}\right)$ and diabase emplaced during the late Permian period $\left(\beta \mu_{4}\right)$. The diabase displays an obvious circular structure in anticlines extending northwest to southeast and is controlled or transformed by several faults extending northwest by north, northeast by north, and northeast by east (modified after the 1:200000 geologic map from the National Geological Archives of China).

rocks deposited from the early Carboniferous to Middle Triassic periods (359-237 Ma). Basic igneous rock (i.e., diabase) emplaced during the late Permian period (260-252 Ma) within the Upper Carboniferous to Permian (323-252 Ma) limestone bearing banded chert/dolomite and Lower Permian (299-272 Ma) siliceous rock/clay rock/limestone bearing banded chert display an obvious circular structure in anticlines $^{1}$. These anticlines extend northwest to southeast and are controlled or transformed by several faults extending northwest by north, northeast by north, and northeast by east. Black nephrite is situated in the southwest limb of an anticline and occurs at the contact zone between diabase ${ }^{2}$ and carbonate rock.

According to local miners, the black nephrite was first discovered under houses in the village of Xiannv, and this was considered a secondary deposit. Mining of the primary deposit started in late 2012 but was prohibited by the local government the following year for conservation reasons. Fieldwork for this

${ }^{1}$ In structural geology, an anticline is a type of fold that is an arch-like shape with the oldest rock layer in the center and the younger rock layer lying on either side symmetrically. A typical anticline is convex up, in which the curvature is greatest at the hinge or crest, and the limbs are the sides of the fold that dip away from the hinge. On the regional geologic map of the Guangxi black nephrite primary deposit, the progressing age of the rock strata toward the core (from the Triassic to Carboniferous periods) is evidence of anticlines. In addition, each anticlinal fold plunges in all directions to form a circular or elongate structure, and the nephrite deposit is situated in the southwest limb of the middle fold, which extends northwest to southwest.

${ }^{2}$ Diabase (or dolerite or microgabbro) is a mafic, holocrystalline, shallow intrusive rock commonly occurring as dikes and sills and exhibiting a typically fine texture of euhedral lath-shaped plagioclase crystals set in a finer matrix of augite, with minor olivine, magnetite, and ilmenite. For example, igneous rocks in the Guangxi black nephrite deposit are diabase emplaced during the late Permian period. 

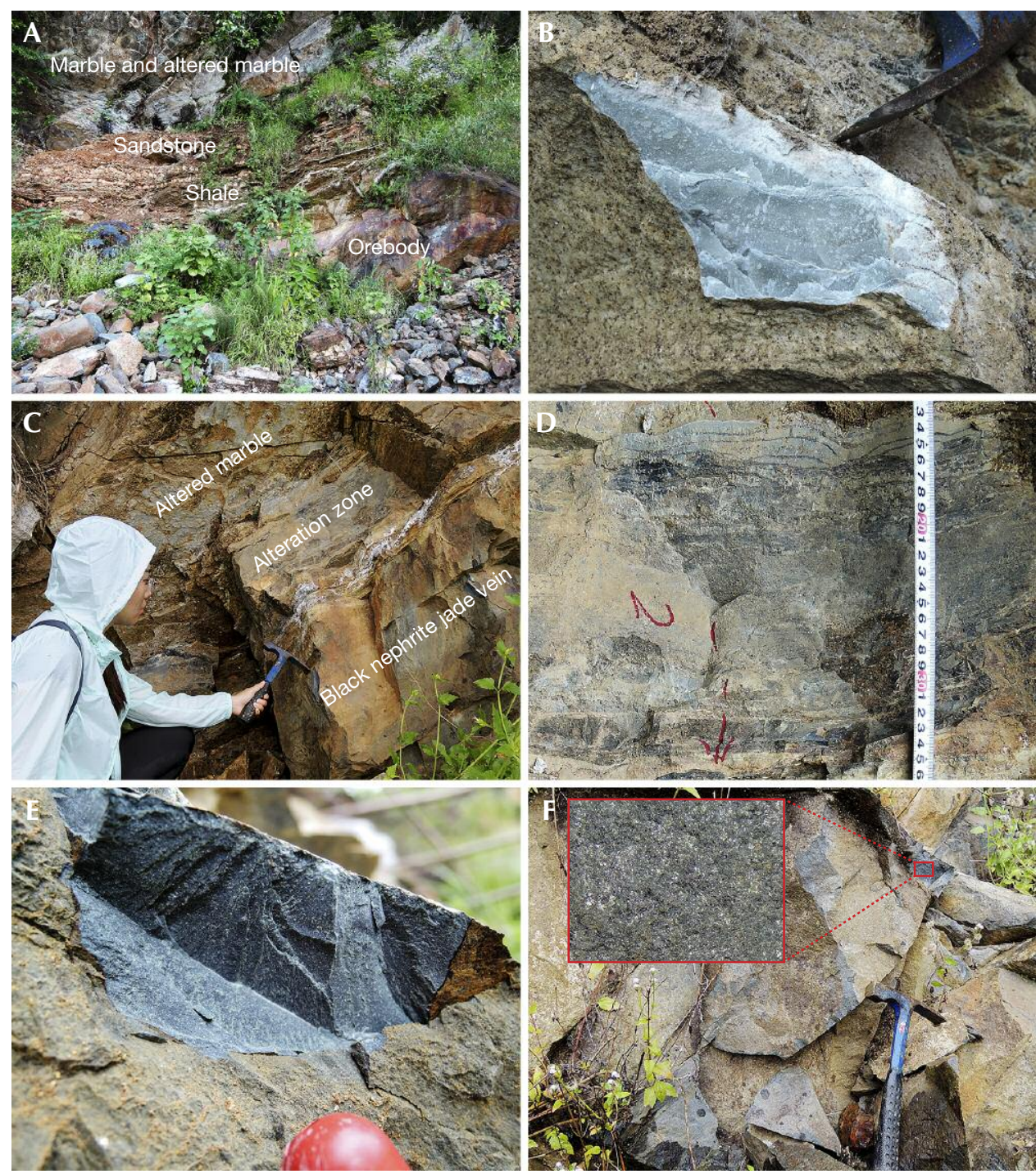

Figure 4. Characteristics of the Guangxi primary deposit. A: Layers include a small exposed outcrop of marble and altered marble subjected to metasomatic diopsidization, silicification, albitization, and tremolitization/actinolitization; residual thin-bedded sedimentary sandstone/ shale; and orebody bearing black nephrite. B: Marble formed by thermal metamorphism of limestone showing medium- to fine-grained crystalloblastic texture and flashes of calcite on cleavage planes. C: An alteration zone with a black nephrite vein about $30 \mathrm{~cm}$ thick underlies the altered marble. D: The banded structure of the alteration zone consists of typical metamorphic minerals such as garnet, clinopyroxene, stilpnomelane, and amphibole. E: A fracture in the black nephrite shows its compact and fine-grained texture. F: Diabase underlying the black nephrite vein shows the typical texture of lath-shaped plagioclase crystals set in a matrix of clinopyroxene. Photos by Qian Zhong and Lijian Qi. study was done in August 2017 and August 2018 at the primary deposit, located 538 meters above sea level at $24^{\circ} 01^{\prime} 38.23^{\prime \prime} \mathrm{N}, 107^{\circ} 27^{\prime} 39.61^{\prime \prime} \mathrm{E}$. The deposit contained many scattered diabase fragments due to previous mining activities. A small exposed outcrop of marble (figure 4B) and altered marble (figure 4C) was subjected to metasomatic diopsidization, silicification, albitization, and tremolitization/actinolitization. Residual thin-bedded sedimentary sandstone/ shale and orebody bearing black nephrite are distributed from top to bottom (figure 4A). Underlying the altered marble is an alteration zone with an obviously banded structure and spatial inhomogeneity (figures 4C and 4D). Typical metamorphic minerals such as garnet, clinopyroxene, stilpnomelane, and amphibole occur in different bands. A black nephrite vein about $30 \mathrm{~cm}$ thick was layered in the lower part (figure 4C). A fracture revealed that the jade is very compact and fine-grained (figure 4E). Diabase is mainly distributed under the vein, and the typical texture of the lath-shaped plagioclase crystals set in a matrix of clinopyroxene could be observed in the fracture (figure 4F).

Because of the subtropical climate, a thin yellowish brown to reddish brown weathering crust similar to iron rust is very common at the surface of the rocks in the primary deposit (figures 5A and 5B). The weathering crust on the black nephrite rocks from the secondary deposit has a yellow color like that of loess mud (figures 5C and 5D). Therefore, black nephrite rough mined from the Guangxi primary and secondary deposits is referred to in the market as "iron rust crust rock" and "loess mud crust rock," respectively. 
A

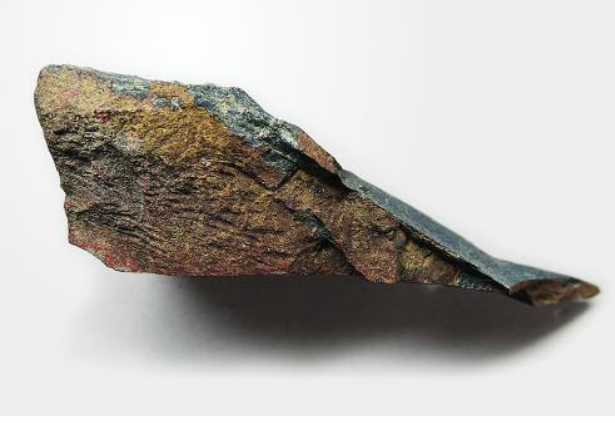

C

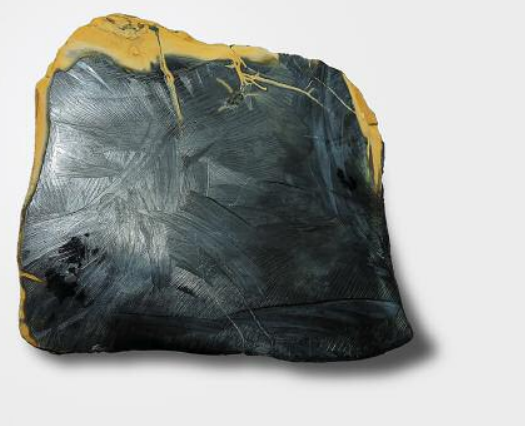

B

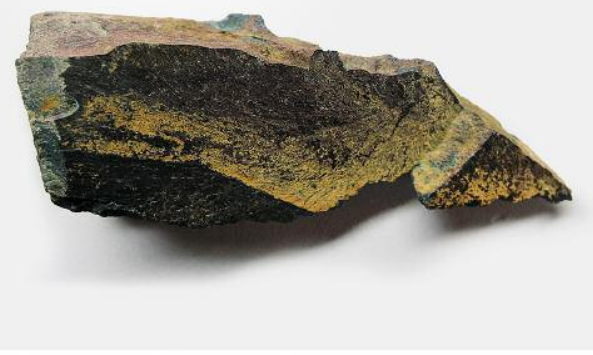

D

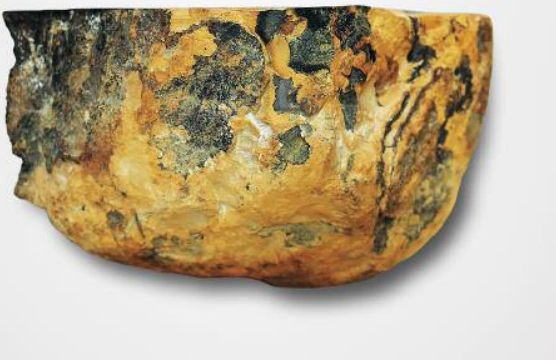

Figure 5. A and B: Black nephrite rough from Guangxi with a typical angular shape. These were collected from the jade vein in the primary deposit shown in Figure 4 and then analyzed as samples $G B-11$ and $G B$ 12 , showing a thin yellowish brown to reddish brown weathering crust similar to iron rust. $C$ and D: Black nephrite jade rough with a typical round shape, collected from the secondary deposit. The rock weighs $2.1 \mathrm{~kg}$ and shows a yellow weathering crust similar to loess mud. Photos by Qian Zhong.

\section{MATERIALS AND METHODS}

Materials. Twelve pieces of black nephrite rough (GB-01 through GB-12) from Guangxi were investigated for this study. GB-01 through GB-09 were supplied by local miners, and GB-10 through GB-12 were collected from the primary deposit during fieldwork. We cut and polished the rough into plate samples, $1.10-6.13 \mathrm{~mm}$ thick and weighing $0.84-38.11 \mathrm{ct}$ (see table 1 photos in natural light), and further polished them into thin sections with various thicknesses to meet the requirements of different measurements.

Analytical Methods. All measurements were collected with equipment at the Laboratory of Gem and Technological Materials of Tongii University, unless otherwise specified. The refractive indices of 12 black nephrite plate samples were measured using a refractometer (by normal reading from flat wafers), and specific gravity was measured hydrostatically with an electronic balance. Ultraviolet fluorescence reactions were examined with a long-wave/shortwave UV lamp. Color, luster, and transparency of the plate samples were observed in natural light, and the color of the thin sections (0.73-0.97 mm thick) was examined in transmitted light.

Petrographic features were studied with a Nanjing Jiangnan Novel Optics BM2100 polarized light microscope. Six thin sections (GB-04, GB-05, GB-06,
GB-08, GB-09, and GB-10) with a standard thickness of $0.03 \mathrm{~mm}$ were observed in both plane- and crosspolarized light. Microstructures on the fractured surface of sample GB-06 were observed using a Hitachi S-4700 scanning electron microscope (SEM) with an accelerating voltage of $15 \mathrm{kV}$ at the Analysis and Testing Center of Suzhou University.

\section{In Brief}

- Black nephrite from Guangxi in southern China exhibited a yellow or green color in transmitted light for thinner samples and displayed a high refractive index and specific gravity due to a high iron content.

- The relative intensities of $(\mathrm{Mg})_{3} \mathrm{OH},\left(\mathrm{Mg}_{2} \mathrm{Fe}^{2+}\right) \mathrm{OH}$, $\left(\mathrm{MgFe}_{2}^{2+}\right) \mathrm{OH}$, and $\left(\mathrm{Fe}^{2+}\right)_{3} \mathrm{OH}$ vibration bands in the mid- and near-infrared and Raman spectra indicate $\mathrm{Mg}^{2+}-\mathrm{Fe}^{2+}$ isomorphous substitution in $M_{1}$ and $M_{3}$ positions.

- Mineral assemblages including actinolite/ferro-actinolite, andradite, diopside, and epidote suggest a Caskarn metasomatism occurring at the contact zone between diabase intrusions and limestone bearing siliceous rock.

Backscattered electron (BSE) images and chemical compositions of minerals in 12 black nephrite thin 
TABLE 1. Gemological properties and mineral compositions of black nephrite from Guangxi.

\begin{tabular}{|c|c|c|c|c|c|c|c|c|c|}
\hline $\begin{array}{l}\text { Sample } \\
\text { no. }\end{array}$ & $\begin{array}{l}\text { Weight } \\
\text { (ct) }\end{array}$ & Luster & Transparency & $\begin{array}{l}\text { UV } \\
\text { fluorescence }\end{array}$ & $\begin{array}{l}\text { Refractive } \\
\text { index }\end{array}$ & $\begin{array}{l}\text { Specific } \\
\text { gravity }\end{array}$ & Natural light ${ }^{\mathrm{a}}$ & Transmitted light ${ }^{b}$ & Mineral composition ${ }^{c}$ \\
\hline GB-01 & 0.84 & Greasy to vitreous & Opaque & Inert & 1.645 & 3.141 & & & Actinolite (>98\%) \\
\hline GB-02 & 1.41 & Greasy to vitreous & Opaque & Inert & 1.645 & 3.149 & & & Actinolite (>98\%) \\
\hline GB-03 & 2.07 & Greasy to vitreous & Opaque & Inert & 1.645 & 3.148 & & & $\begin{array}{l}\text { Actinolite (92-95\%), } \\
\text { stilpnomelane }(5-8 \%)\end{array}$ \\
\hline GB-04 & 27.50 & Greasy to vitreous & Opaque & Inert & 1.625 & 3.062 & & & $\begin{array}{l}\text { Actinolite }(75-80 \%) \text {, diopside } \\
(13-15 \%) \text {, quartz }(5-8 \%) \text {, } \\
\text { stilpnomelane }(1-3 \%)\end{array}$ \\
\hline GB-05 & 23.09 & Greasy to vitreous & Opaque & Inert & 1.640 & 3.015 & & & $\begin{array}{l}\text { Actinolite }(65-70 \%) \text {, } \\
\text { stilpnomelane }(23-25 \%) \text {, } \\
\text { epidote }(3-5 \%) \text {, apatite }(1- \\
3 \%) \text {, andradite }(<1 \%)\end{array}$ \\
\hline GB-06 & 11.23 & Greasy to vitreous & Opaque & Inert & 1.645 & 3.146 & & & $\begin{array}{l}\text { Actinolite (97-99\%), apatite } \\
(1-3 \%)\end{array}$ \\
\hline GB-08 & 17.52 & Greasy to vitreous & Opaque & Inert & 1.650 & 3.405 & & & $\begin{array}{l}\text { Ferro-actinolite }(60-65 \%), \text { Fe } \\
\text { sulfides }(27-30 \%), \\
\text { stilpnomelane }(8-10 \%)\end{array}$ \\
\hline GB-09 & 15.59 & Greasy to vitreous & Opaque & Inert & 1.650 & 3.251 & & & $\begin{array}{l}\text { Ferro-actinolite }(75-80 \%) \text {, Fe } \\
\text { sulfides }(10-15 \%), \\
\text { stilpnomelane }(3-5 \%), \\
\text { andradite }(3-5 \%) \text {, diopside } \\
(<1 \%) \text {, quartz }(<1 \%)\end{array}$ \\
\hline GB-10 & 8.80 & Greasy to vitreous & Opaque & Inert & 1.626 & 3.015 & & & $\begin{array}{l}\text { Actinolite (92-95\%), } \\
\text { stilpnomelane (5-8\%) }\end{array}$ \\
\hline GB-11 & 38.11 & Greasy to vitreous & Opaque & Inert & 1.645 & 3.142 & & & $\begin{array}{l}\text { Actinolite }(93-95 \%) \text {, } \\
\text { stilpnomelane }(3-5 \%) \text {, apatite } \\
(1-3 \%)\end{array}$ \\
\hline GB-12 & 30.00 & Greasy to vitreous & Opaque & Inert & 1.648 & 3.197 & & & $\begin{array}{l}\text { Ferro-actinolite (97-99\%), } \\
\text { stilpnomelane }(1-3 \%)\end{array}$ \\
\hline $\begin{array}{l}\text { apotos o } \\
{ }^{b} \text { Photos O } \\
{ }^{c} \text { Volume }\end{array}$ & f plate sa & $\begin{array}{l}\text { Imples with a thickness } \\
\text { tion samples with a th }\end{array}$ & $\begin{array}{l}\text { of } 1.10 \text { to } 6.13 \\
\text { ickness of } 0.73 t\end{array}$ & $\begin{array}{l}\mathrm{nm}, \text { taken in n } \\
0.97 \mathrm{~mm} \text {, tak }\end{array}$ & tural light. & nsmitted & ht. & cope. & \\
\hline
\end{tabular}


TABLE 2. Electron microprobe analysis and calculations of actinolite and ferro-actinolite in black nephrite from Guangxi.

\begin{tabular}{|c|c|c|c|c|c|c|c|c|c|c|c|c|}
\hline Sample & GB-01 & GB-02 & GB-03 & GB-04 & GB-05 & GB-06 & GB-07 & GB-08 & GB-09 & GB-10 & GB-11 & GB-12 \\
\hline \multicolumn{13}{|l|}{ Oxides (wt.\%) } \\
\hline $\mathrm{SiO}_{2}$ & 54.07 & 53.44 & 54.20 & 55.69 & 53.93 & 54.65 & 53.36 & 52.33 & 52.33 & 56.14 & 55.09 & 53.38 \\
\hline $\mathrm{Al}_{2} \mathrm{O}_{3}$ & 0.33 & 0.36 & 0.33 & 0.47 & 0.39 & 0.27 & 0.32 & 0.43 & 0.27 & 0.32 & 0.24 & 0.31 \\
\hline $\mathrm{TiO}_{2}$ & 0.02 & 0.01 & 0.01 & 0.02 & 0.01 & 0.02 & $b d l^{a}$ & 0.03 & 0.01 & 0.02 & 0.01 & 0.01 \\
\hline $\mathrm{Cr}_{2} \mathrm{O}_{3}$ & 0.01 & 0.01 & bdl & 0.01 & 0.02 & 0.01 & bdl & 0.02 & 0.01 & 0.01 & 0.01 & 0.01 \\
\hline $\mathrm{FeO}^{\mathrm{b}}$ & 19.42 & 19.49 & 19.46 & 11.67 & 19.31 & 19.50 & 21.70 & 25.61 & 25.75 & 15.31 & 19.66 & 23.39 \\
\hline $\mathrm{MgO}$ & 11.48 & 11.25 & 11.45 & 16.90 & 12.08 & 11.19 & 9.70 & 7.47 & 7.23 & 14.13 & 11.15 & 8.94 \\
\hline $\mathrm{MnO}$ & 0.21 & 0.20 & 0.21 & 0.18 & 0.23 & 0.25 & 0.24 & 0.21 & 0.16 & 0.33 & 0.20 & 0.19 \\
\hline $\mathrm{CaO}$ & 11.55 & 11.29 & 11.53 & 12.31 & 11.60 & 11.36 & 10.85 & 11.43 & 11.60 & 11.09 & 11.25 & 11.74 \\
\hline $\mathrm{Na}_{2} \mathrm{O}$ & 0.09 & 0.09 & 0.06 & 0.07 & 0.10 & 0.08 & 0.13 & 0.11 & 0.08 & 0.10 & 0.17 & 0.05 \\
\hline $\mathrm{K}_{2} \mathrm{O}$ & 0.05 & 0.05 & 0.05 & 0.04 & 0.08 & 0.25 & 0.82 & 0.04 & 0.02 & 0.48 & 0.70 & 0.03 \\
\hline Total & 97.22 & 96.18 & 97.29 & 97.36 & 97.75 & 97.59 & 97.12 & 97.68 & 97.46 & 97.92 & 98.47 & 98.04 \\
\hline \multicolumn{13}{|c|}{ Ions per 23 oxygens } \\
\hline $\mathrm{Si}^{4+}$ & 7.987 & 7.975 & 7.997 & 7.923 & 7.898 & 8.055 & 8.015 & 7.947 & 7.993 & 8.049 & 8.080 & 7.995 \\
\hline${ }^{\mathrm{IV}} \mathrm{Al}^{3+}$ & 0.013 & 0.025 & 0.003 & 0.077 & 0.068 & bdl & bdl & 0.053 & 0.007 & bdl & bdl & 0.005 \\
\hline$\sum \mathrm{T}$ & 8.000 & 8.000 & 8.000 & 8.000 & 7.966 & 8.055 & 8.015 & 8.000 & 8.000 & 8.049 & 8.080 & 8.000 \\
\hline${ }^{\mathrm{V}} \mathrm{Al}^{3+}$ & 0.044 & 0.038 & 0.055 & 0.002 & bdl & 0.046 & 0.057 & 0.025 & 0.041 & 0.054 & 0.041 & 0.050 \\
\hline $\mathrm{Ti}^{4+}$ & 0.002 & 0.001 & 0.001 & 0.002 & 0.001 & 0.002 & bdl & 0.003 & 0.001 & 0.002 & 0.001 & 0.001 \\
\hline $\mathrm{Cr}^{3+}$ & 0.001 & 0.002 & bdl & 0.001 & 0.002 & 0.001 & bdl & 0.002 & 0.002 & 0.001 & 0.001 & 0.001 \\
\hline $\mathrm{Fe}^{3+}$ & 0.275 & 0.338 & 0.276 & 0.288 & 0.450 & 0.180 & 0.229 & 0.259 & 0.137 & 0.323 & 0.080 & 0.168 \\
\hline $\mathrm{Fe}^{2+}$ & 2.124 & 2.094 & 2.125 & 1.101 & 1.915 & 2.224 & 2.496 & 2.993 & 3.152 & 1.513 & 2.332 & 2.762 \\
\hline $\mathrm{Mg}^{2+}$ & 2.528 & 2.502 & 2.518 & 3.584 & 2.637 & 2.459 & 2.173 & 1.691 & 1.647 & 3.019 & 2.439 & 1.995 \\
\hline $\mathrm{Mn}^{2+}$ & 0.026 & 0.025 & 0.026 & 0.022 & 0.029 & 0.032 & 0.030 & 0.027 & 0.020 & 0.040 & 0.024 & 0.024 \\
\hline$\Sigma C$ & 5.000 & 5.000 & 5.001 & 5.000 & 5.034 & 4.944 & 4.985 & 5.000 & 5.000 & 4.952 & 4.918 & 5.001 \\
\hline $\mathrm{Ca}^{2+}$ & 1.827 & 1.805 & 1.822 & 1.877 & 1.820 & 1.793 & 1.745 & 1.860 & 1.899 & 1.703 & 1.768 & 1.883 \\
\hline $\mathrm{Na}^{+}$ & 0.025 & 0.026 & 0.017 & 0.020 & 0.028 & 0.023 & 0.038 & 0.033 & 0.023 & 0.027 & 0.047 & 0.013 \\
\hline$\Sigma \mathrm{B}$ & 1.852 & 1.831 & 1.839 & 1.897 & 1.848 & 1.816 & 1.783 & 1.893 & 1.922 & 1.730 & 1.815 & 1.896 \\
\hline $\mathrm{K}^{+}$ & 0.010 & 0.010 & 0.010 & 0.007 & 0.015 & 0.046 & 0.156 & 0.007 & 0.004 & 0.088 & 0.130 & 0.005 \\
\hline$\sum \mathrm{A}$ & 0.010 & 0.010 & 0.010 & 0.007 & 0.015 & 0.046 & 0.156 & 0.007 & 0.004 & 0.088 & 0.130 & 0.005 \\
\hline $\mathrm{Mg} / \mathrm{Mg}+\mathrm{Fe}^{2+}$ & 0.543 & 0.544 & 0.542 & 0.765 & 0.579 & 0.525 & 0.465 & 0.361 & 0.343 & 0.666 & 0.511 & 0.419 \\
\hline Amphibole & $\mathrm{Act}^{\mathrm{C}}$ & Act & Act & Act & Act & Act & Fe-Act & Fe-Act & Fe-Act & Act & Act & Fe-Act \\
\hline
\end{tabular}

sections (0.03 mm thick) and plate samples were obtained with a JEOL JXA-8230 electron microprobe at the State Key Laboratory of Marine Geology of Tongji University using an accelerating voltage of $15 \mathrm{kV}$, a beam current of $10 \mathrm{nA}$, and a beam diameter less than $5 \mu \mathrm{m}$ in wavelength-dispersive spectrometry mode. Natural and synthetic mineral standards (SPI Supplies) were used to calibrate all quantitative analyses, and a ZAF program was used for data reduction. Two to six points per sample/mineral were analyzed.
Cations per formula unit of amphiboles were calculated based on 23 oxygen atoms and 15 cations. The total iron content was first estimated as $\mathrm{FeO}$, and $\mathrm{Fe}^{2+} / \mathrm{Fe}^{3+}$ ratios were then estimated by a charge-balance method on a stoichiometric sum of cations (Schumacher and Wang, 2001).

Infrared absorption spectra of 12 plate samples were obtained with a Bruker Tensor 27 Fouriertransform infrared spectrometer. For measurements in the 4000 to $400 \mathrm{~cm}^{-1}$ range, nearly $1.5 \mathrm{mg}$ of pow- 

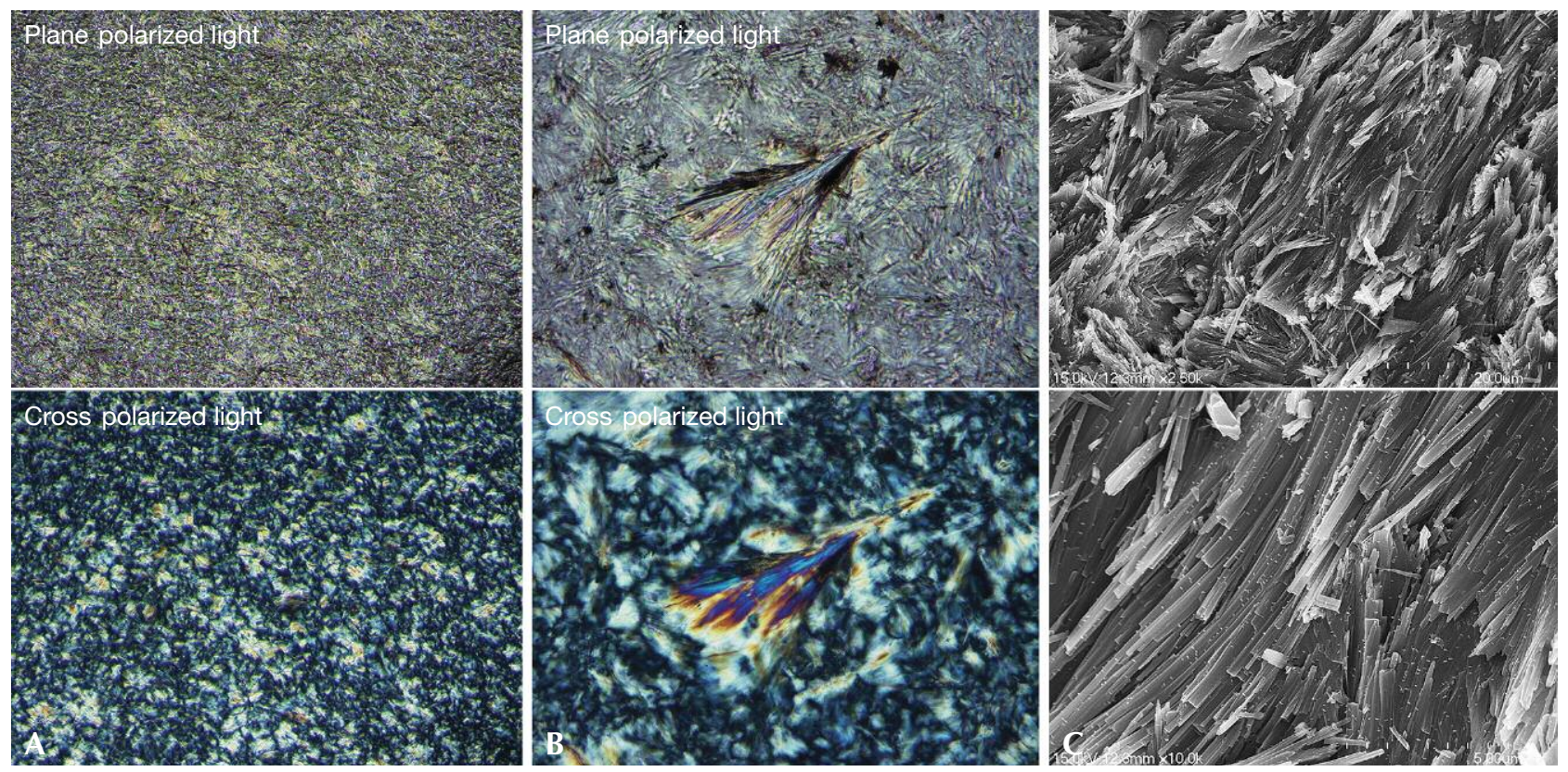

Figure 6. Polarized optical and scanning electron microscope (SEM) images of actinolite in black nephrite from Guangxi. A: In sample GB-06, fine-grained and felted actinolite fibers (top) show first-order orange to second-order bluish green interference colors in cross-polarized light (bottom). Image width $1.36 \mathrm{~mm}$. B: In GB-04, some actinolite fibers are arranged to form a radial structure. Image width $0.68 \mathrm{~mm}$. C: SEM images of GB-06 show actinolite fibers nearly $20 \times 0.5 \mu \mathrm{m}$ in size (top) and some actinolite fibers arranged to form a parallel structure (bottom). Photos by Qian Zhong.

der was scraped from each sample and dispersed in $150 \mathrm{mg}$ of $\mathrm{KBr}$ to prepare pressed pellets. In the 8000 to $4000 \mathrm{~cm}^{-1}$ range, thin-section samples $(0.73-0.97$ mm thick) were tested directly. Both types of spectra were recorded in transmission mode at a resolution of $4 \mathrm{~cm}^{-1}$, a scanning frequency of $10 \mathrm{kHz}$, and 32 scans. Infrared spectra in the 3700 to $3600 \mathrm{~cm}^{-1}$ range were obtained using a Bruker Lumos micro-Fouriertransform infrared spectrometer in attenuated total reflectance mode with medium pressures, at a resolution of $4 \mathrm{~cm}^{-1}$ and 32 scans per area $(150 \times 150$ $\mu \mathrm{m}^{2}$.

Raman spectra of 12 plate samples were collected using a Horiba Jobin Yvon LabRAM HR Evolution confocal micro-Raman spectrometer equipped with a $532 \mathrm{~nm}$ Nd:YAG laser. The laser was focused on the mineral surface using an optical microscope with a $100 \times$ objective, and the laser power was around 50 $\mathrm{mW}$. Depolarized spectra in the 4000 to $100 \mathrm{~cm}^{-1}$ range were acquired using a grating with $600 \mathrm{gr} / \mathrm{mm}$, a scan time of $20 \mathrm{~s}$, and 3 scans.

Ultraviolet/visible/near-infrared (UV-Vis-NIR) spectra of 12 thin sections (0.13-0.49 mm thick) were obtained with a GEM-3000 spectrophotometer at a resolution of $1 \mathrm{~nm}$, an integration time of $80 \mathrm{~ms}$, a smoothness degree of 2 , and 30 scans.

\section{RESULTS}

Gemological Properties. The gemological properties of the 12 nephrite samples from Guangxi are listed in table 1. All plate samples (1.10-6.13 mm thick) were black and opaque and exhibited a greasy to vitreous luster in natural light. The thin sections $(0.73-$ $0.97 \mathrm{~mm}$ thick) showed two different kinds of mottled color in transmitted light. Three samples (GB-01, GB-02, and GB-10) were greenish yellow to brownish yellow, while the remaining nine ranged from pale green to yellowish green to green. All samples were inert to both long- and short-wave UV radiation and displayed an RI of 1.625 to 1.650 and an SG of 3.015 to 3.405. In addition, different amounts of minor minerals were included in almost every sample. The most obvious were minerals with a typical metallic luster and brassy yellow color in plate samples GB-08 and GB-09.

Petrographic Features and Microstructures. Polarized optical images (figures 6A and 6B) combined with electron microprobe data (table 2) showed that the black nephrite samples from Guangxi consisted mainly of fine-grained, felted actinolite with first-order orange to second-order bluish green interference colors in crosspolarized light. (For more on orders of interference col- 


\section{Box A: Orders of InTerference Colors}

The order of interference color is used to describe colors observed in thin sections with a petrographic microscope when identifying minerals, particularly anisotropic minerals. There is a path difference caused by the difference in velocity between the two rays resolved by the anisotropic (doubly refractive) substance between crossed polarizers, which is known as the retardation. The retardation $(\mathrm{r})$ increases linearly with both the thickness $(t)$ of a sample and the birefringence $\left(\mathrm{n}_{2}-\mathrm{n}_{1}\right): \mathrm{r}=\mathrm{t}\left(\mathrm{n}_{2}-\mathrm{n}_{1}\right)$. When the two rays enter the upper polarizer, the retardation results in destructive interference for certain wavelengths to give the interference col- ors. To distinguish the colors produced by different multiples of wavelengths, the interference colors are divided into "orders," with the end of each order marked by a red color representing one full wavelength retardation (Delly, 2003). For example, the first order starts with black and gray, followed by yellow and orange, and ends with "first-order red." The second order is made up of violet, blue, green, yellow, orange, and "second-order red." Interested readers should refer to the Michel-Lévy chart (see Delly, 2003), which shows the interrelationships between thickness, birefringence, and interference colors. ors, see box A.) Faint light yellow/light green pleochroism was observed in plane-polarized light. SEM images (figure 6C) further indicated that the actinolite fibers were nearly $20 \times 0.5 \mu \mathrm{m}$ in size. Some fibers formed either a radial (figure 6B) or a parallel (figure 6C, bottom) structure. Polarized optical images and BSE images (figure 7) combined with electron microprobe data (table 3) revealed various amounts of Fe sulfides (up to $30 \%$ ), stilpnomelane (up to $25 \%$ ), diopside (up to $15 \%$ ), quartz (up to $8 \%$ ), epidote (up to $5 \%$ ), andradite (up to $5 \%$ ), and apatite (up to $3 \%$ ) (table 1 ).
Chemical Compositions. Average chemical compositions and cations per formula unit of amphiboles for the 12 samples are shown in table 2. According to Leake et al. (1997) and Hawthorne et al. (2012), amphiboles in black nephrite belong to the calcic group, characterized by $7.898-8.080$ atoms per formula unit (apfu) of Si, 0.004-0.156 apfu of K on the A site, and 1.703-1.899 and 0.013-0.047 apfu of Ca and $\mathrm{Na}$ on the $\mathrm{B}$ site, respectively. In addition, the $\mathrm{Mg} /\left(\mathrm{Mg}+\mathrm{Fe}^{2+}\right)$ ratio of amphiboles in GB-07, GB-08, GB-09, and GB-12 ranged from 0.343 to 0.465 , and

TABLE 3. Electron microprobe analysis of minor minerals in black nephrite from Guangxi.

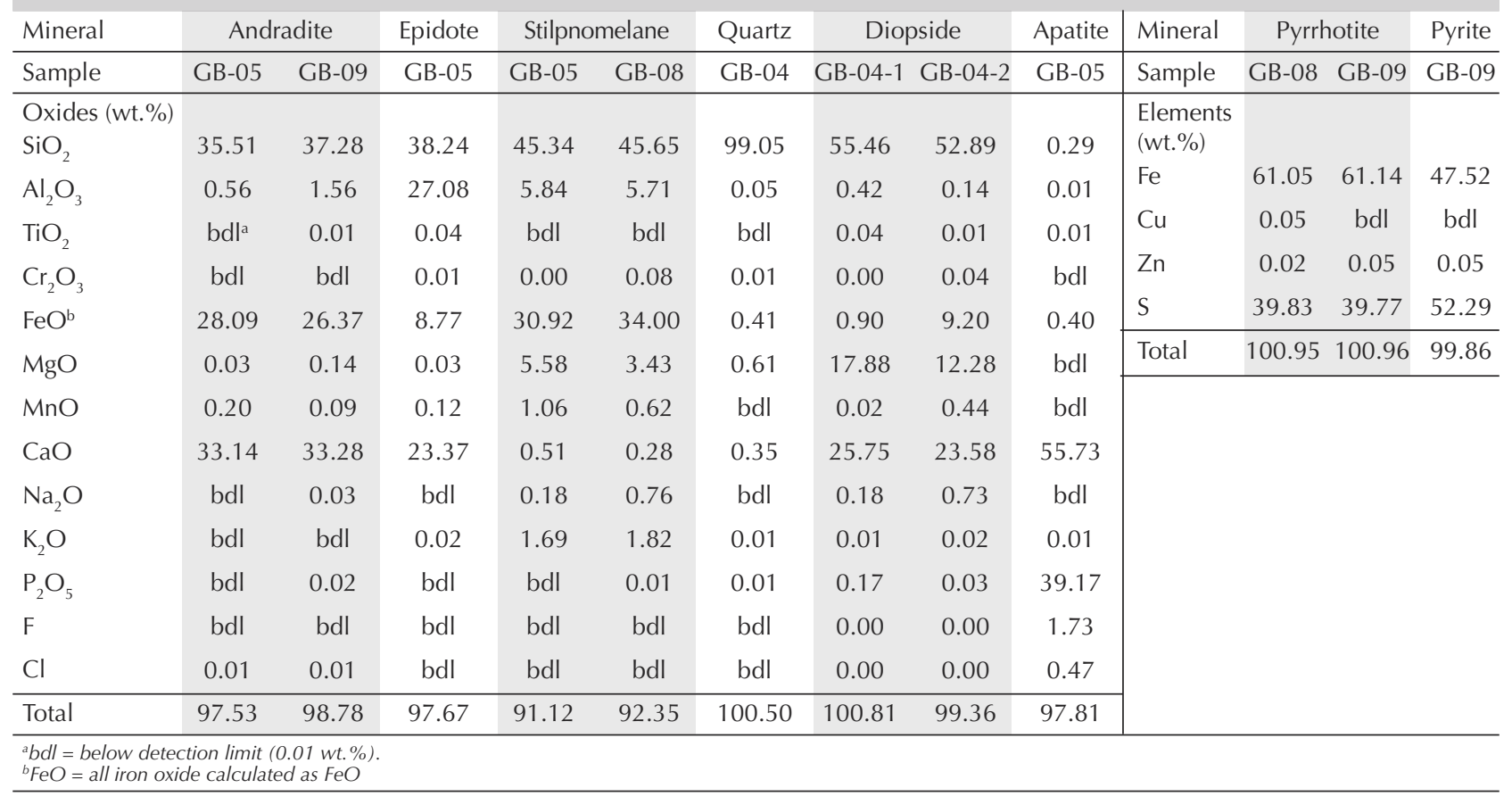



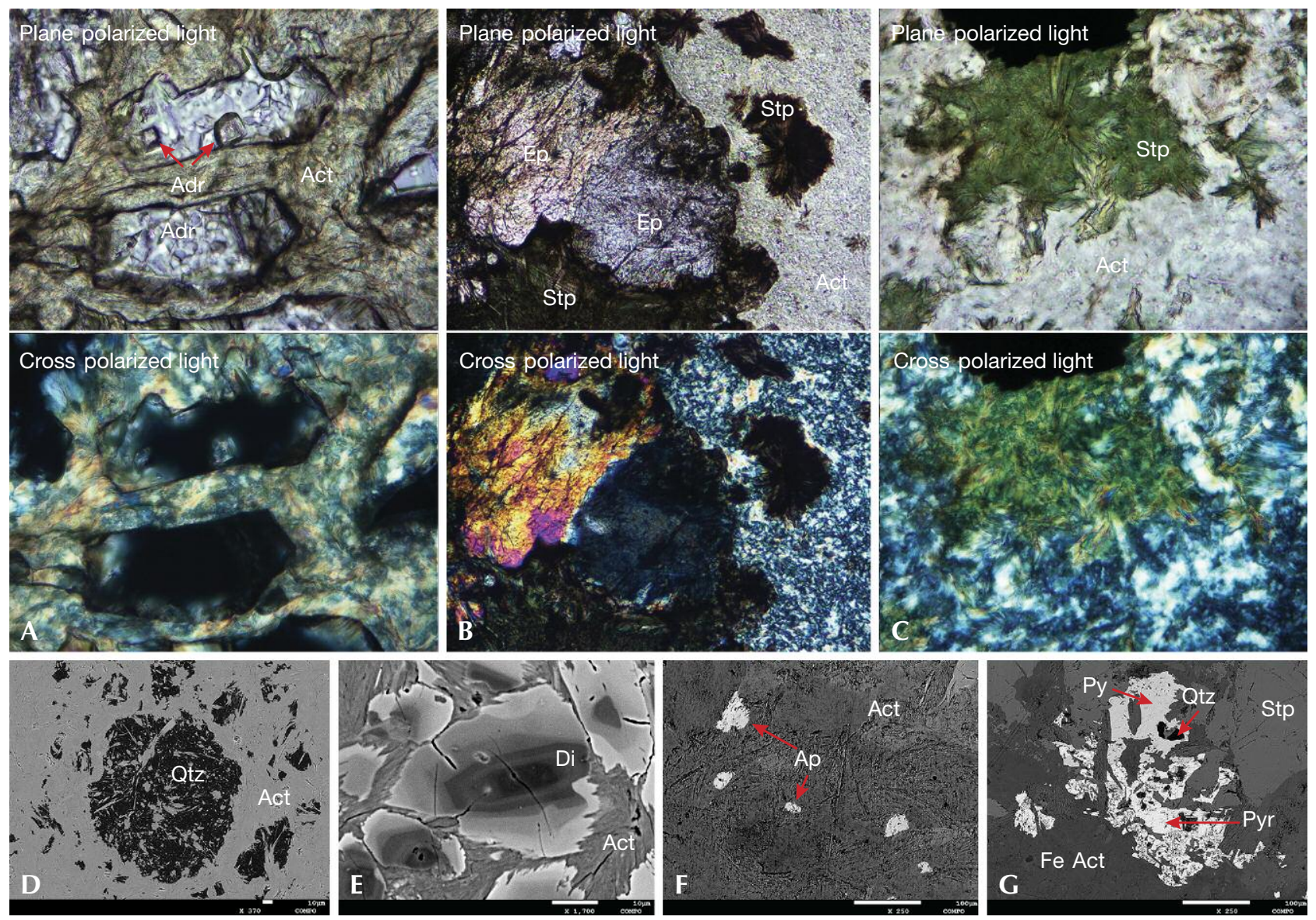

Figure 7. Polarized optical and back-scattered electron (BSE) images of minor minerals in black nephrite from Guangxi. A: In sample GB-10, actinolite veins cut the andradite, which includes two euhedral rhombic dodecahedral andradite crystals. Image width $0.68 \mathrm{~mm}$. B: In GB-05, epidote crystals are replaced by fine-grained actinolite and needle-, rod-, or fiber radial-shaped stilpnomelane. Image width $2.72 \mathrm{~mm}$. C: Sample GB-08 consists mainly of brownish green stilpnomelane with radial fiber arrangements. Image width $0.68 \mathrm{~mm}$. D: The BSE image of sample GB-04 shows subhedral quartz crystals or relics up to $120 \mathrm{\mu m}$ replaced by actinolite along fractures or cracks. E: GB-04 shows actinolite replacing subhedral diopside crystals up to $30 \mu \mathrm{m}$ with zoning structures due to chemical compositional zonings. F: GB-05 shows anhedral apatite crystals up to $50 \mathrm{um}$ distributed within actinolite aggregates. G: GB-09 shows irregularly shaped pyrrhotite, pyrite, stilpnomelane, ferro-actinolite, and quartz grains of varying brightness due to different average atomic numbers. Abbreviations: actinolite (Act), ferro-actinolite (FeAct), andradite (Adr), epidote (Ep), stilpnomelane (Stp), pyrrhotite (Pyr), pyrite (Py), quartz (Qtz), diopside (Di), and apatite $(A p)$. Photos by Qian Zhong.

these were identified as ferro-actinolite. The ratio ranged from 0.511 to 0.765 in the remaining samples, which were identified as actinolite. Therefore, the black nephrite from Guangxi was composed mainly of actinolite or ferro-actinolite. All samples contained abundant iron (11.67-25.75 wt.\% FeO) and minor manganese $(0.16-0.33$ wt. \% $\mathrm{MnO})$, titanium (below 0.03 wt. \% $\mathrm{TiO}_{2}$ ), and chromium (below 0.02 wt. \% $\mathrm{Cr}_{2} \mathrm{O}_{3}$ ).

Representative chemical compositions of minor minerals including andradite, epidote, stilpnomelane, quartz, diopside, apatite, pyrrhotite, and pyrite (figure 7) are shown in table 3 . The andradite was composed mainly of $\mathrm{CaO}$ (33.14-33.28 wt.\%), FeO (26.37-28.09 wt.\%), and $\mathrm{SiO}_{2}$ (35.51-37.28 wt.\%). The stilpnomelane (brown in GB-05 and green in GB08) was characterized by a high iron content $(30.92$ and $34.00 \mathrm{wt}$ \% FeO, respectively). In diopside, iron was lower and magnesium was higher in the core (table 3, GB-04-1) than in the rim (table 3, GB-04-2), which explains its zoning structure of darkness and brightness in the BSE image (figure 7E). The pyrrhotite in sample GB-09 had a typical chemical composition of $61.14 \mathrm{wt}$. \% iron and $39.77 \mathrm{wt} . \%$ sul- 


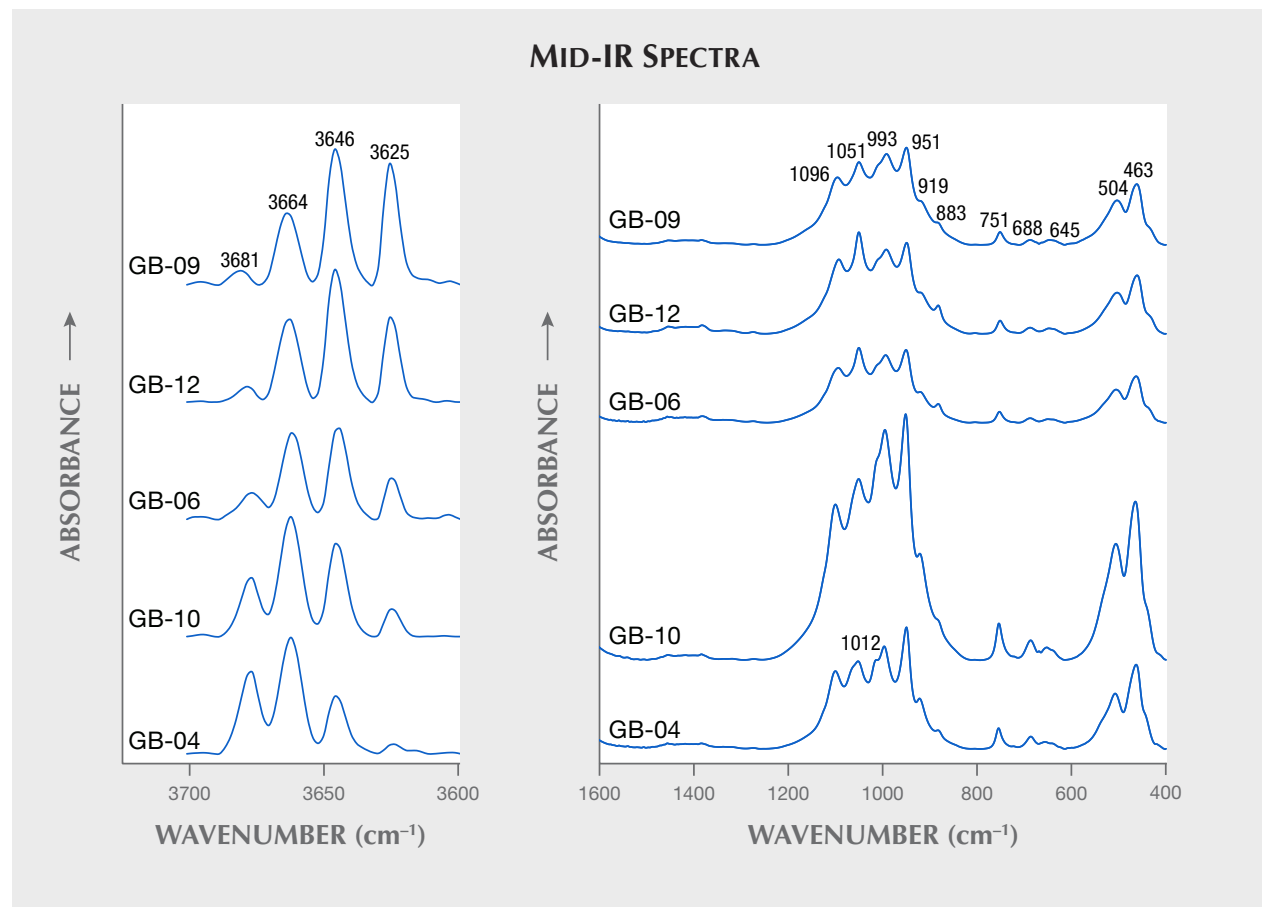

Figure 8. Mid-infrared spectra of five typical plate samples from Guangxi in the 3700$3600 \mathrm{~cm}^{-1}$ (left) and $1600-400 \mathrm{~cm}^{-1}$ (right) ranges. The spectra show bands related to $\mathrm{M}_{3}$-OH asymmetric stretching modes; Si-OSi, O-Si-O, and M-O stretching modes; $\mathrm{Si}-\mathrm{O}$ bending modes; and $\mathrm{O}$ $H$ translational modes of actinolite or ferroactinolite. ( $\mathrm{M}$ is $a n a b$ breviation for a metal ion.) Spectra are offset vertically for clarity.

fur, while the pyrite's was 47.52 wt. \% iron and 52.29 wt. $\%$ sulfur.

Infrared Spectroscopy. Mid-Infrared Spectroscopy. Mid-infrared spectra (figure 8) of the black nephrite plate samples were characterized by one set of bands in the 3700 to $3600 \mathrm{~cm}^{-1}$ range and three sets $(1200$ $800 \mathrm{~cm}^{-1}, 800-600 \mathrm{~cm}^{-1}$, and $\left.600-400 \mathrm{~cm}^{-1}\right)$ in the 1600 to $400 \mathrm{~cm}^{-1}$ range, typical of $M_{3}-\mathrm{OH}(M$ is an abbreviation for a metal ion) and $\left[\mathrm{Si}_{4} \mathrm{O}_{11}\right]$ vibrations in actinolite or ferro-actinolite, respectively (Wen et al., 1988). The asymmetric and symmetric stretching modes of the Si$\mathrm{O}-\mathrm{Si}$ and $\mathrm{O}-\mathrm{Si}-\mathrm{O}$ groups appear mainly at approximately 1096, 1051, 1012, 993, 951, 919, 883, 751, 688, and $645 \mathrm{~cm}^{-1}$. The bands near 504 and $463 \mathrm{~cm}^{-1}$ are related to the bending modes of the Si-O group, stretching modes of the $M-O$ group, and translational modes of the O-H group. The bands around 3681, 3664, 3646, and $3625 \mathrm{~cm}^{-1}$ are related to the asymmetric stretching modes of the $M_{3}-\mathrm{OH}$ group. No absorption bands related to minor mineral phases were observed.

Near-Infrared Spectroscopy. Near-infrared spectra (figure 9) of the black nephrite thin sections were mainly characterized by the combination modes of the $M_{3}$ $\mathrm{OH}, \mathrm{Si}-\mathrm{O}$ groups, or water and the multiple vibration modes of the hydroxyl group in actinolite or ferro-actinolite. Four strong and sharp bands around 7185, 7156, 7117 , and $7078 \mathrm{~cm}^{-1}$ are related to the first overtone of $M_{3}-\mathrm{OH}$ asymmetric stretching modes (Burns and
Strens, 1966). The broad band centered at nearly 5226 $\mathrm{cm}^{-1}$ is assigned to the combination modes of water adsorbed within the actinolite or ferro-actinolite aggregates. The combination modes of the $M_{3}-\mathrm{OH}$ and Si-O groups appear at approximately 4295 and $4161 \mathrm{~cm}^{-1}$.

Figure 9. Near-infrared spectra of five typical thin-section samples (0.73-0.97 mm thick) from Guangxi showing bands related to the first overtone of $\mathrm{M}_{3}-\mathrm{OH}$ asymmetry stretching modes as well as the combination modes of water, $\mathrm{M}_{3}-\mathrm{OH}$, and Si-O groups of actinolite or ferro-actinolite in the $8000-4000 \mathrm{~cm}^{-1}$ range. Spectra are offset vertically for clarity.

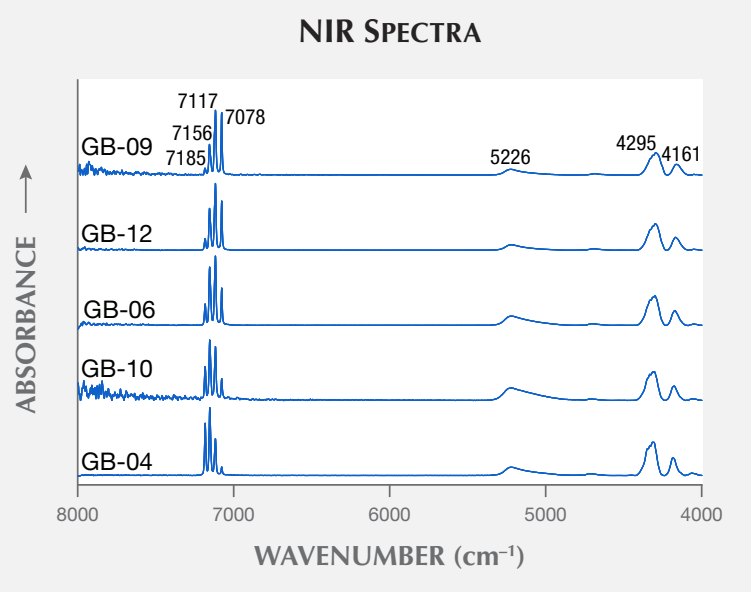




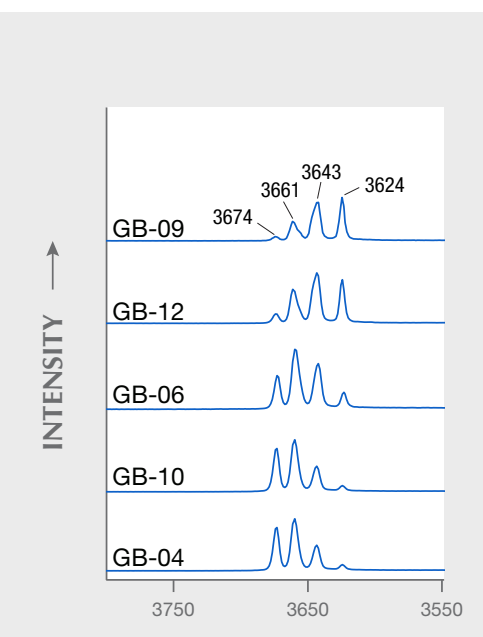

RAMAN SHIFT $\left(\mathrm{cm}^{-1}\right)$

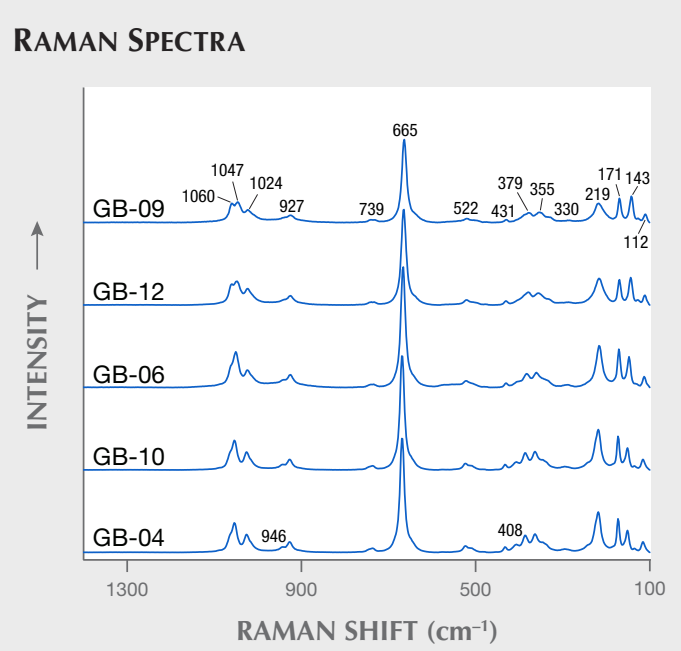

Figure 10. Raman spectra of five typical plate samples from Guangxi showing peaks related to $\mathrm{M}_{3}-\mathrm{OH}$ stretching modes of actinolite or ferro-actinolite in the $3700-3600 \mathrm{~cm}^{-1}$ range, as well as Si-O and SiO-Si stretching modes, Si-O bending modes, and lattice vibration modes in the 1200-100 $\mathrm{cm}^{-1}$ range. Spectra are offset vertically for clarity.
Raman Spectroscopy. Raman spectra (figure 10) of the black nephrite plate samples were primarily characterized by peaks in the 3700 to $3600 \mathrm{~cm}^{-1}$ and 1200 to $100 \mathrm{~cm}^{-1}$ ranges, which are typical of $M_{3}-\mathrm{OH}$ and $\left[\mathrm{Si}_{4} \mathrm{O}_{11}\right]$ vibrations in actinolite or ferro-actinolite. Peaks at approximately 1060, 1047, 1024, 946, and $927 \mathrm{~cm}^{-1}$ are related to the stretching modes of the Si-O group, and those at 739 and $665 \mathrm{~cm}^{-1}$ are related to the stretching modes of the Si-O-Si group. The bending modes of the Si-O group appear mainly at approximately 522 and $431 \mathrm{~cm}^{-1}$. Peaks at around $408,379,355,330,219,171,143,128$, and $112 \mathrm{~cm}^{-1}$ are assigned to the lattice vibration modes. Four sharp Raman peaks near 3674, 3661, 3643, and 3624 $\mathrm{cm}^{-1}$ are related to the stretching modes of $M_{3}-\mathrm{OH}$ groups (Lu, 2005; Feng et al., 2017).

UV-Vis-NIR Spectroscopy. Black nephrite thin sections (0.13-0.49 mm thick) with greenish yellow to brownish yellow (samples GB-01, GB-02, and GB-10) and pale green to yellowish green to green (samples GB-04, GB-06, and GB-09) colors in transmitted light exhibited similar but slightly different absorption features in the 220 to $1000 \mathrm{~nm}$ range; these are named type I (figure 11, left) and type II (figure 11, right) spectra. Considering chemical composition (table 2) and previous studies (Marfunin, 1984; Lu, 2005), the significant transition metals that contributed to the colors and UV-Vis-NIR spectra of the Guangxi black nephrite were iron and manganese. In both types of spectra, there are two broad bands centered at 726$737 \mathrm{~nm}$ and 916-935 nm, which are due to $\mathrm{Fe}^{2+} \leftrightarrow \mathrm{Fe}^{3+}$ intervalence charge transfer and combinations of $\mathrm{Fe}^{2+}$ and $\mathrm{Fe}^{3+}$ electron transition, respectively. The strong absorptions in the blue-ultraviolet range with a maximum at 440-460 $\mathrm{nm}$ for type I spectra and 355-405 nm for type II spectra are both due to $\mathrm{O}^{2-\leftrightarrow} \mathrm{Fe}^{3+}$ charge transfer. In type II spectra, shoulders at $445 \mathrm{~nm}$ and 625-635 nm are due to $\mathrm{Fe}^{3+} / \mathrm{Mn}^{2+}$ and $\mathrm{Fe}^{3+}$ electron transition, respectively. Absorptions mentioned above result in a transmission centered at 628-645 $\mathrm{nm}$ or $515-553 \mathrm{~nm}$ in the visible range, which leads to a greenish yellow/brownish yellow or pale green/yellowish green/green bodycolor, respectively.

However, there is no obvious difference in transition metal contents between the samples with two types of color. We infer that differences in their UVVis-NIR spectra result from different modes of occurrence of iron and manganese in black nephrite.

\section{DISCUSSION}

Iron's Influence on RI, SG, and Vibrational Spectra. The samples from Guangxi have an iron content $(11.67-25.75$ wt. \% FeO) that is higher than that of white nephrite (0.07-1.09 wt.\% FeO, four deposits; Siqin et al., 2012), green nephrite (0.12-4.93 wt.\% $\mathrm{FeO}$, nine deposits; Siqin et al., 2012), and even other black nephrite (4.11-14.39 \% FeO, Xinjiang; Liu et al., 2011a). For that reason, they have a higher RI (1.625-1.650) and SG (3.015-3.405) than any nephrite previously reported (see Zhang, 2006). Likewise, significant substitution of iron for magnesium indicates that black nephrite from Guangxi is primarily composed of actinolite or ferro-actinolite instead of tremolite. Figure 12 shows that the samples' RI and SG values increase with iron content. Due to a large amount of minor minerals included in some samples (see table 1), related data can deviate from the normal 
TYPE I

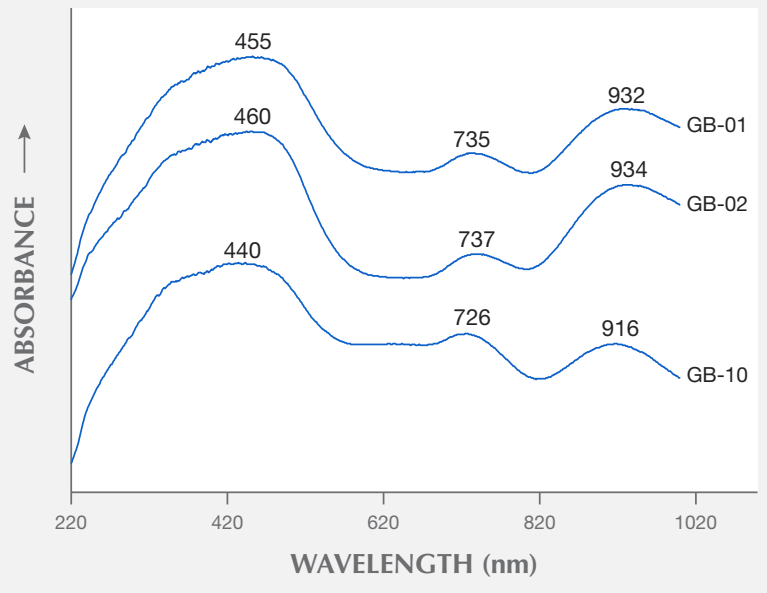

TYPE II

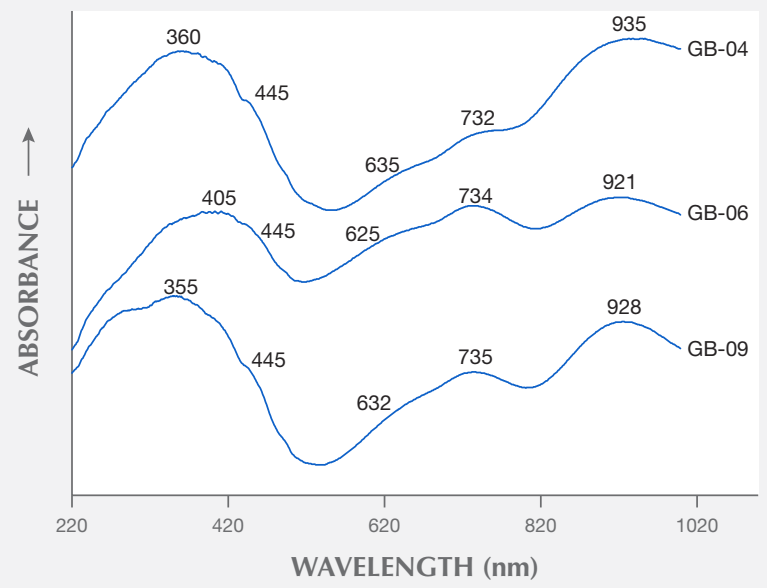

Figure 11. UV-Vis-NIR spectra of six typical thin-section samples (0.13-0.49 mm thick) from Guangxi with greenish yellow/brownish yellow (type I) and pale green/yellowish green/green (type II) colors in transmitted light. The peaks in the 220-1000 $\mathrm{nm}$ range are attributable mainly to iron and manganese.

trend. For sample GB-04, the relatively high RI and SG are believed to result from the diopside content. The relatively low RI and SG of GB-05 are likely caused by its stilpnomelane content. The highest SG, in sample GB-08, is probably related to Fe sulfides in addition to a high iron content.

As seen in figure 13, the mid-infrared, near-infrared, and Raman spectra of the black nephrite are characterized by four $M_{3}-\mathrm{OH}$ vibration bands in the
3700 to $3600 \mathrm{~cm}^{-1}$ or 7240 to $7020 \mathrm{~cm}^{-1}$ range. In the crystal structure of calcic amphiboles, each hydroxyl group is coordinated to three neighboring metal ions at two $M_{1}$ positions and one $M_{3}$ position, forming a pseudo-trigonal symmetrical $\left(M_{1} M_{1} M_{3}\right) \mathrm{OH}$ group. $M_{1}$ and $M_{3}$ positions are occupied mainly by $\mathrm{Mg}^{2+}$ or $\mathrm{Fe}^{2+}$, forming a perfect isomorphous substitution. For white nephrite composed of tremolite nearly free of iron, there exists only one sharp $(\mathrm{Mg})_{3} \mathrm{OH}$ band. For

Figure 12. Scatterplots showing that the refractive index (left) and specific gravity (right) of the samples increase with iron content as FeO. Data deviating from the normal trend likely due to included minor minerals such as diopside (GB-04), stilpnomelane (GB-05), and Fe sulfides (GB-08) are specially marked. For detailed data, see tables 1 and 2 .
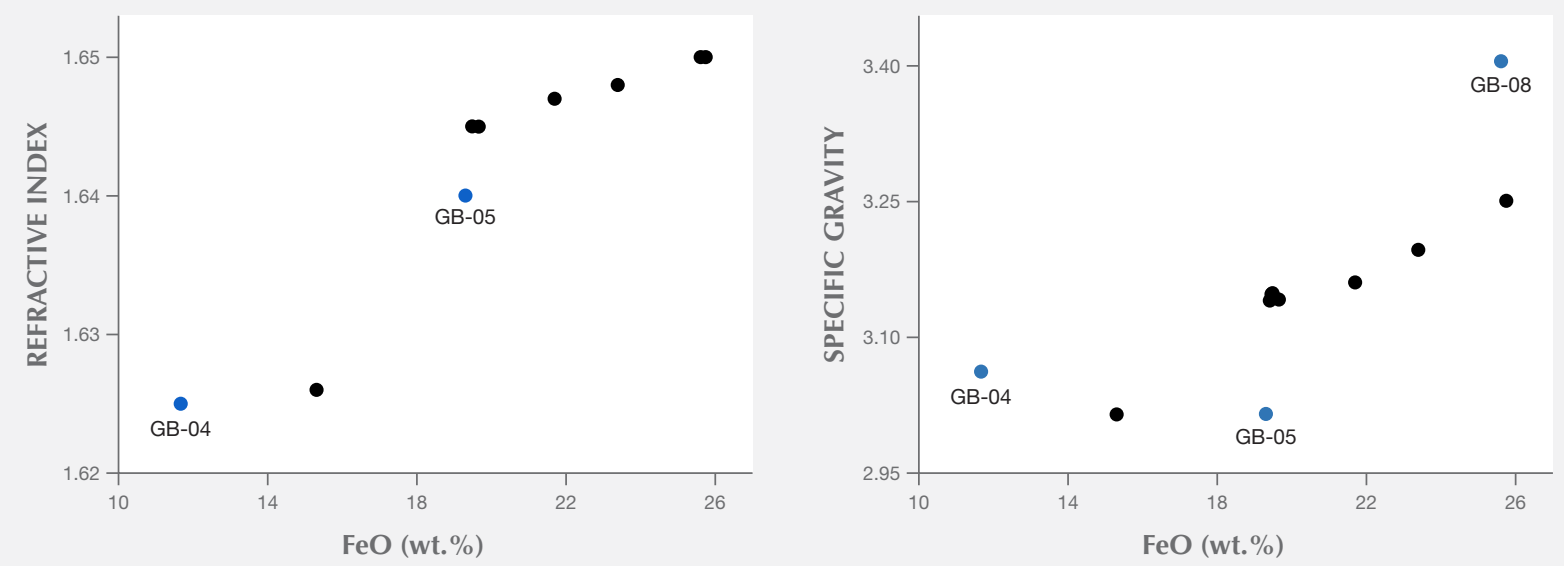

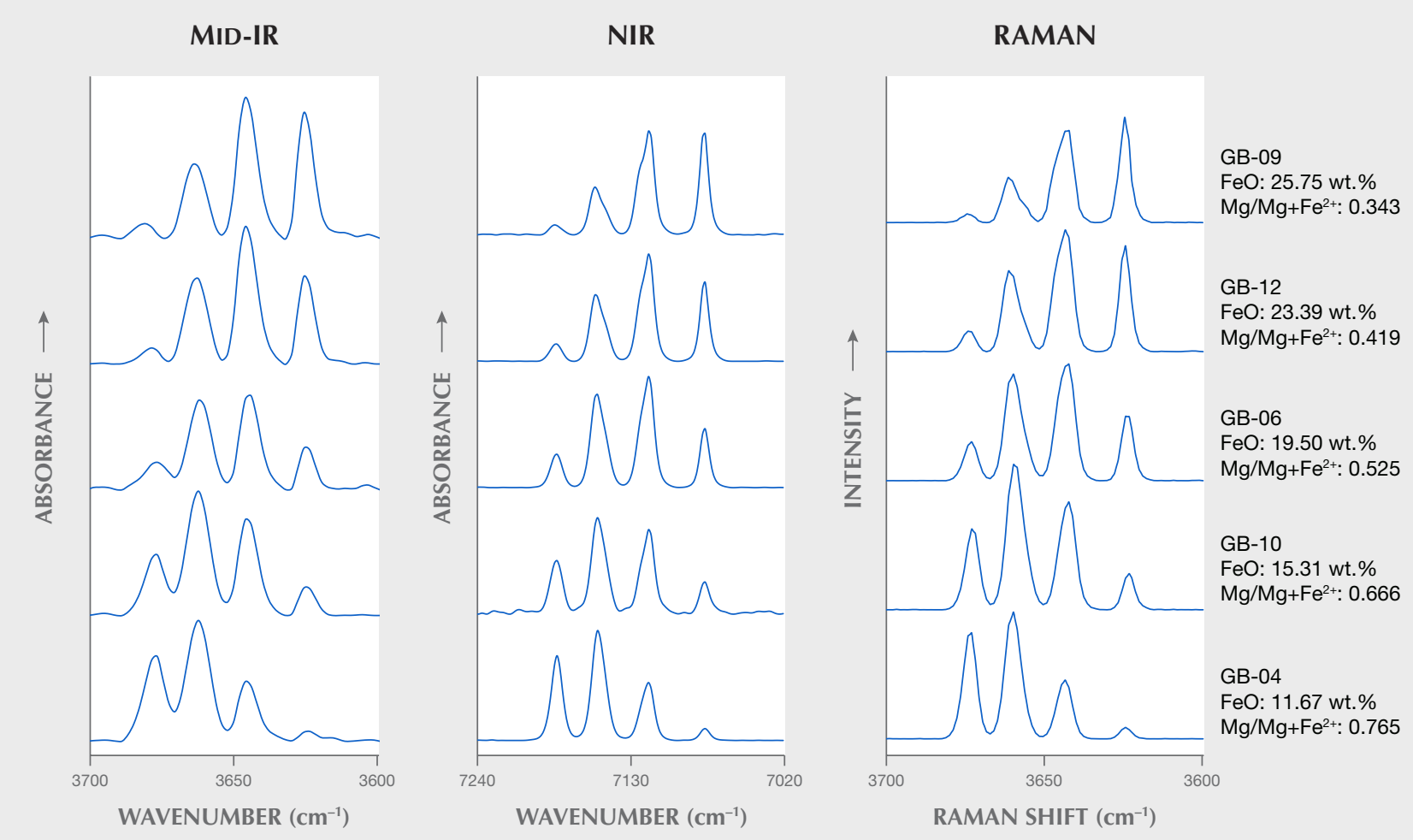

Figure 13. Mid-infrared, near-infrared, and Raman spectra of the samples are characterized by four $(\mathrm{Mg})_{3} \mathrm{OH}$, $\left(\mathrm{Mg}_{2} \mathrm{Fe}^{2+}\right) \mathrm{OH},\left(\mathrm{MgFe}_{2}^{2+}\right) \mathrm{OH}$, and $\left(\mathrm{Fe}^{2+}\right)_{3} \mathrm{OH}$ bands in the 3700-3600 $\mathrm{cm}^{-1}$ or $7240-7020 \mathrm{~cm}^{-1}$ range. With rising iron content, relative intensities of $(\mathrm{Mg})_{3} \mathrm{OH}$ and $\left(\mathrm{Mg}_{2} \mathrm{Fe}^{2+}\right) \mathrm{OH}$ bands decrease while relative intensities of $\left(\mathrm{MgFe}^{2+}{ }_{2}\right) \mathrm{OH}$ and $\left(\mathrm{Fe}^{2+}\right)_{3} \mathrm{OH}$ bands increase. Spectra are offset vertically for clarity.

greenish white and green nephrite, bands related to $\left(\mathrm{Mg}_{2} \mathrm{Fe}^{2+}\right) \mathrm{OH}$ and $\left(\mathrm{MgFe}^{2+}{ }_{2}\right) \mathrm{OH}$ gradually appear as iron content increases (Burns and Strens, 1966; Feng et al., 2017). For the black nephrite from Guangxi, $M_{3}-\mathrm{OH}$ vibration bands are split into four bands due to high iron content. According to Burns and Strens (1966) and $\mathrm{Lu}(2005)$, four bands in the mid-infrared and Raman spectra near 3681/3674, 3664/3661, $3646 / 3643$, and $3625 / 3624 \mathrm{~cm}^{-1}$ are respectively attributed to $(\mathrm{Mg})_{3} \mathrm{OH},\left(\mathrm{Mg}_{2} \mathrm{Fe}^{2+}\right) \mathrm{OH},\left(\mathrm{MgFe}^{2+}{ }_{2}\right) \mathrm{OH}$, and $\left(\mathrm{Fe}^{2+}\right)_{3} \mathrm{OH}$ fundamental vibrations. Four bands in the near-infrared spectra near $7185,7156,7117$, and
$7077 \mathrm{~cm}^{-1}$ are respectively attributed to the first overtone of $(\mathrm{Mg})_{3} \mathrm{OH},\left(\mathrm{Mg}_{2} \mathrm{Fe}^{2+}\right) \mathrm{OH},\left(\mathrm{MgFe}^{2+}{ }_{2}\right) \mathrm{OH}$, and $\left(\mathrm{Fe}^{2+}\right)_{3} \mathrm{OH}$ fundamental vibrations (table 4).

For sample GB-04, with the lowest iron content $-11.67 \mathrm{wt} . \% \mathrm{FeO}$, and an $\mathrm{Mg} /\left(\mathrm{Mg}+\mathrm{Fe}^{2+}\right)$ ratio of 0.765 - the relative intensity of the $M_{3}-\mathrm{OH}$ bands is $\left(\mathrm{Mg}_{2} \mathrm{Fe}^{2+}\right) \mathrm{OH}>(\mathrm{Mg})_{3} \mathrm{OH}>\left(\mathrm{MgFe}^{2+}{ }_{2}\right) \mathrm{OH}>$ $\left(\mathrm{Fe}^{2+}\right)_{3} \mathrm{OH}$. The $\left(\mathrm{Fe}^{2+}\right)_{3} \mathrm{OH}$ band is very weak (figure 13). For GB-10, GB-06, and GB-12, with increasing iron content, $\left(\mathrm{MgFe}^{2+}{ }_{2}\right) \mathrm{OH}$ and $\left(\mathrm{Fe}^{2+}\right)_{3} \mathrm{OH}$ bands are increasingly stronger as they are more closely related to $\mathrm{Fe}^{2+}$, while $\left(\mathrm{Mg}_{2} \mathrm{Fe}^{2+}\right) \mathrm{OH}$ and $(\mathrm{Mg})_{3} \mathrm{OH}$ bands are

TABLE 4. Frequencies $\left(\mathrm{cm}^{-1}\right)$ of $\left(M_{1} M_{1} M_{3}\right)-\mathrm{OH}$ bands in vibrational spectra and their assignments in black nephrite from Guangxi.

\begin{tabular}{lcccc}
\hline Type of $\left(M_{1} M_{1} M_{3}\right)$-OH group & $(\mathrm{Mg})_{3} \mathrm{OH}$ & $\left(\mathrm{Mg}_{2} \mathrm{Fe}^{2+}\right) \mathrm{OH}$ & $\left(\mathrm{MgFe}_{2}{ }_{2}\right) \mathrm{OH}$ & $3646-3645$ \\
\hline Mid-infrared frequency & $3681-3677$ & $3664-3662$ & 3646 & $3625-3624$ \\
Near-infrared frequency & $7185-7183$ & $7156-7154$ & 7117 & 7077 \\
Raman frequency & $3674-3673$ & $3661-3660$ & $3643-3642$ & $3624-3623$ \\
\hline
\end{tabular}


increasingly weaker. For sample GB-09, with the highest iron content-25.75 wt.\% FeO, and an $\mathrm{Mg} /\left(\mathrm{Mg}+\mathrm{Fe}^{2+}\right)$ ratio of 0.343 - the relative intensity is $\left(\mathrm{Fe}^{2+}\right)_{3} \mathrm{OH} \approx\left(\mathrm{MgFe}^{2+}{ }_{2}\right) \mathrm{OH}>\left(\mathrm{Mg}_{2} \mathrm{Fe}^{2+}\right) \mathrm{OH}>(\mathrm{Mg})_{3} \mathrm{OH}$, and the $(\mathrm{Mg})_{3} \mathrm{OH}$ band is very weak. Therefore, iron content and $\mathrm{Mg}^{2+}-\mathrm{Fe}^{2+}$ isomorphous substitution affect the relative intensity of $M_{3}-\mathrm{OH}$ vibration bands, in addition to their number and frequency.

There are also differences in the Raman spectra of the black nephrite samples in the $1400-100 \mathrm{~cm}^{-1}$ range (figure 10, right). For instance, with increasing iron content, the strongest peak at $669 \mathrm{~cm}^{-1}$ gradually shifts toward the lower frequency to $665 \mathrm{~cm}^{-1}$. The relative intensity of the $1060 \mathrm{~cm}^{-1} / 1047 \mathrm{~cm}^{-1}$ peaks becomes stronger, while the peaks at nearly 946 and $408 \mathrm{~cm}^{-1}$ become weaker. And in mid-infrared spectra (figure 8, right), the intensity of the band at approximately $1012 \mathrm{~cm}^{-1}$ becomes weaker with increasing iron content.

Genesis of Black Nephrite. Located at the boundary zone between diabase and limestone bearing siliceous rock, Guangxi black nephrite is a product of contact metasomatism ${ }^{3}$ occurring after basic magma intrusion into carbonate rock. Therefore, this deposit is of contact metasomatic and skarn origin. Skarn deposits can generally be grouped into $\mathrm{Ca}-, \mathrm{Mg}$-, and $\mathrm{Mn}$-skarn by their mineral assemblages. Typical Mg-skarn nephrite from Xinjiang, which is related to dolomitic marbles rich in magnesium (29.61-30.76 wt.\% CaO, 22.08$22.52 \mathrm{wt} . \% \mathrm{MgO}$, and a Ca/Mg ratio of 0.94-1.01; Liu et al., 2011b), contains Mg-bearing minerals such as olivine, spinel, phlogopite, serpentine, and talc (Tang et al., 1994; Liu et al., 2015). Low-magnesium marbles (54.19 wt.\% CaO, 0.21 wt. \% $\mathrm{MgO}$, and a $\mathrm{Ca} / \mathrm{Mg}$ ratio of 183) found in the deposit and the presence of calcic minerals such as actinolite/ferro-actinolite, andradite, diopside, and epidote in the samples (figure 7 and table 3) strongly suggest that the Guangxi deposit is a Caskarn deposit. The skarn appears to be spatially zoned as the Xinjiang deposit, with different minerals distributed at different distances from the intrusive rock (figure 4). Moreover, it is remarkable that stilpnomelane, a minor mineral in the black nephrite from Guangxi, can be used as a fingerprint, as it has not been reported to exist in other nephrite deposits.
The $\mathrm{Fe}^{2+} /\left(\mathrm{Mg}+\mathrm{Fe}^{2+}\right)$ ratio of actinolite/ferro-actinolite in black nephrite from Guangxi (0.235-0.657) is much higher than that of tremolite-actinolite in D-type (0.001-0.074) and S-type (0.064-0.118) nephrite (Siqin et al., 2012), which is determined by diabase related to its formation. From a chemical composition perspective, basic diabase is richer in iron and magnesium and poorer in silicon (12.0015.50 wt. \% FeO, 3.02-6.59 wt.\% $\mathrm{MgO}$, and 45.9048.30 wt. $\% \mathrm{SiO}_{2}$; Zhang and Xiao, 2014), compared to intermediate-acid diorite/granodiorite (2.68-6.16 wt. \% FeO, 2.27-4.39 wt. \% MgO, and 50.57-58.62 wt. \% $\mathrm{SiO}_{2}$; Tang et al., 1994). Hence, diabase and siliceous rock in limestone are likely sources of magnesium and silicon, respectively, whereas the limestone itself is the source of calcium. Rare earth elements (REE) with patterns more similar to limestone than diabase (Wang et al., 2014) suggest that the Guangxi black nephrite formed by the replacement of limestone. In addition, hydrous minerals such as actinolite/ferro-actinolite, stilpnomelane, and epidote formed in the metasomatism stage indicate that fluids were also involved. Therefore, it is proposed that actinolite/ferro-actinolite in black nephrite from Guangxi formed by a reaction between limestone bearing siliceous rock and aqueous solutions bearing iron, magnesium, and silicon:

$$
\begin{aligned}
& 2 \mathrm{CaCO}_{3}+8 \mathrm{SiO}_{2}+\mathrm{xFeO}+(5-\mathrm{x}) \mathrm{MgO}+\mathrm{H}_{2} \mathrm{O} \rightarrow \\
& \text { limestone } \\
& \begin{array}{l}
\mathrm{Ca}_{2}\left(\mathrm{Fe}_{\mathrm{x}}, \mathrm{Mg}_{5-\mathrm{x}}\right) \mathrm{Si}_{8} \mathrm{O}_{22}(\mathrm{OH})_{2}+2 \mathrm{CO}_{2} \\
\text { actinolite/ferro-actinolite }
\end{array}
\end{aligned}
$$

The rocks involved in black nephrite formation are limestone bearing siliceous rock and diabase. These are similar to the rocks in the Guizhou deposit. Considering similarities in geographical and tectonic locations and orebody characteristics, we believe that Guangxi and Guizhou represent another large-scale nephrite formation belt in China in addition to the east-west Kunlun Mountains.

\section{CONCLUSIONS}

With a pure color and delicate texture, carvings of black nephrite jade from Guangxi in southern China (figure 14) have been favorably received in the market since mining began in 2012. The material is com-

${ }^{3}$ Contact metasomatism refers to a process of chemical change in the composition of rock in contact with an invading magma, from which fluid constituents are carried out to combine with some of the country-rock constituents to form a new suite of minerals. The Guangxi black nephrite deposit is a typical contact-metasomatic (or skarn) deposit formed in the contact zone between mafic magma intrusions (i.e., diabase) and carbonate rock. 


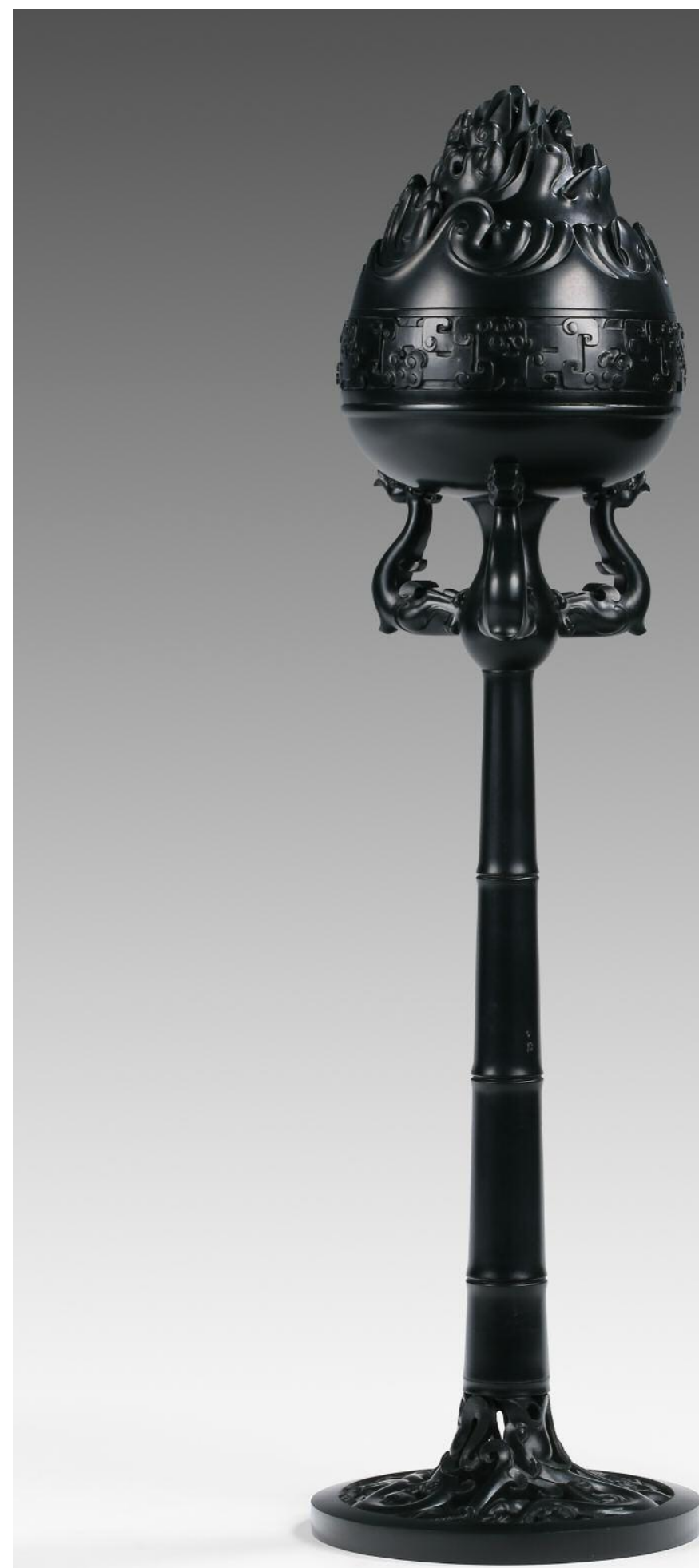

Figure 14. This censer delicately carved from Guangxi black nephrite has a mountain-shaped cover and a bambooshaped stem, with decorative patterns on its body as well as dragon patterns on its joint and pedestal. Courtesy of Hongwei Ma.

posed mainly of fine-grained and felted actinolite or ferro-actinolite, with minor minerals stilpnomelane, andradite, apatite, epidote, quartz, diopside, pyrrho- tite, and pyrite. An abundant iron content-11.67$25.75 \mathrm{wt}$ \% $\mathrm{Fe}$ oxides and an $\mathrm{Mg} /\left(\mathrm{Mg}+\mathrm{Fe}^{2+}\right)$ ratio of $0.765-0.343$ - is the main reason for its high refractive 
index (1.625-1.650) and specific gravity (3.015-3.405). High iron content is also the reason for the black color in natural light for samples with a normal thickness $(1.10-6.13 \mathrm{~mm})$ and the greenish yellow/brownish yellow or pale green/yellowish green/green color in transmitted light for thinner samples $(0.73-0.97$ $\mathrm{mm})$. Moreover, significant isomorphous substitution of $\mathrm{Fe}^{2+}$ for $\mathrm{Mg}^{2+}$ at $M_{1}$ and $M_{3}$ positions in the crystal structure of actinolite or ferro-actinolite is responsible for bands with different intensities appearing at approximately $3681 / 3674,3664 / 3661,3646 / 3643$, and $3625 / 3624 \mathrm{~cm}^{-1}$ in the mid-infrared/Raman spectra, as well as bands at approximately $7185,7156,7117$, and $7077 \mathrm{~cm}^{-1}$ in the near-infrared spectra. These are respectively related to $(\mathrm{Mg})_{3} \mathrm{OH},\left(\mathrm{Mg}_{2} \mathrm{Fe}^{2+}\right) \mathrm{OH}$, $\left(\mathrm{MgFe}^{2+}{ }_{2}\right) \mathrm{OH}$, and $\left(\mathrm{Fe}^{2+}\right)_{3} \mathrm{OH}$ fundamental vibrations as well as their first overtones. As a product of $\mathrm{Ca}$ skarn metasomatism occurring at the contact zone between diabase intrusions and limestone bearing siliceous rock, Guangxi black nephrite originated from source rocks similar to those of Guizhou. It is proposed that the Guangxi and Guizhou nephrite deposits are part of a large-scale jade formation belt in southern China.

\section{ABOUT THE AUTHORS}

Ms. Zhong (Zhongqian2012@163.com) is a PhD student of mineralogy, Dr. Liao (liaozt@tongji.edu.cn, corresponding author) is a professor of tectonic geology, Mr. Qi is a professor of gemology, and Dr. Zhou is an associate professor of gemology, in the State Key Laboratory of Marine Geology, the School of Ocean and Earth Sciences, and the Laboratory of Gem and Technological Materials of Tongji University, Shanghai.

\section{ACKNOWLEDGMENTS}

The authors sincerely thank George E. Harlow, Ahmadjan Abduriyim, and one anonymous reviewer for their constructive comments. We thank Ms. Lingmin Zhang (Tongji University) for help in obtaining electron microprobe data, Mr. Weijian Gao
(Suzhou University, China) for help in acquiring SEM images, and Mr. Bowen Zhao (National Center of Quality Supervision and Inspection on Gold-Silver Products in Shanghai) for help in Raman analyses. The authors are also grateful to Mr. Meng Lai and Ling Li (Tongji University), Mr. Xuanming Yi (Guizhou, China), Mr. Xing Zhou (Guizhou), and Mr. Qisheng Huang (Guangxi) for assistance in field work and sample collections; Mr. Hongwei Ma (Jiangsu, China) for providing photos of Guangxi black nephrite carvings; and Mr. Shiyi Ni (Tongji University) for help in drawing the geological map. This study was funded by the Natural Science Foundation of China (41140023), the Fundamental and Public Project of Geological Exploration Foundation of Guizhou (2016-02), and the Research Project of Science and Technology Committee of Shanghai (15dz2283200).

\section{REFERENCES}

Bureau of Geology and Mineral Resources of Guangxi Zhuang Autonomous Region (1985) Regional Geology of Guangxi Province. Geological Publishing House, Beijing, pp. 156-212, 363-395.

Burns R.G., Strens R.G.J. (1966) Infrared study of the hydroxyl bands in clinoamphiboles. Science, Vol. 153, No. 3738, pp. 890892, http://dx.doi.org/10.1126/science.153.3738.890

Chen Y.L., Niu F.L., Liu R.F., Huang Z.B., Tkalcic H., Sun L., Chan W. (2010) Crustal structure beneath China from receiver function analysis. Journal of Geophysical Research, Vol. 115, No. B3, http://dx.doi.org/10.1029/2009JB006386

Delly J.G. (2003) The Michel-Lévy interference color chart-microscopy's magical color key. https://www.mccrone.com/themichel-levy-interference-color-chart-microscopys-magicalcolor-key

Feng X.Y., Zhang Y., Lu T.J., Zhang H. (2017) Characterization of $\mathrm{Mg}$ and $\mathrm{Fe}$ contents in nephrite using Raman spectroscopy. Ge G, Vol. 53, No. 2, pp. 204-212, http://dx.doi.org/10.5741/ GEMS.53.2.204

Flint D.J., Dubowski E.A. (1990) Cowell nephrite jade deposits. In F.E. Hughes, Ed., Geology of the Mineral Deposits of Australia and Papua New Guinea. Institute of Mineralogy and Metal- lurgy, Melbourne, Australia, Vol. 14, pp. 1059-1062.

Harlow G.E., Sorensen S.S. (2005) Jade (nephrite and jadeitite) and serpentinite: metasomatic connections. International Geology Review, Vol. 47, No. 2, pp. 113-146, http://dx.doi.org/10.2747/ 0020-6814.47.2.113

Harlow G.E., Sorensen S.S., Sisson V.B., Shi G.H. (2014) Chapter 10: The Geology of Jade Deposits. In L.A. Groat, Ed., The Geology of Gem Deposits, 2nd ed. Short Course Handbook Series 44. Mineralogical Association of Canada, Quebec, Canada, pp. 305-374.

Hawthorne F.C., Oberti R., Harlow G.E., Maresch W.V., Martin R.F., Schumacher J.C., Welch M.D. (2012) Nomenclature of the amphibole supergroup. American Mineralogist, Vol. 97, No. 11-12, pp. 2031-2048, http://dx.doi.org/10.2138/am.2012.4276

He M.Y., Zhu Y.N., Li H.B. (2002) Gemmological characteristics of Meiling jade from Liyang, Jiangsu Province. Acta Petrologica et Mineralogica, Vol. 21, No. S1, pp. 99-104.

Jin X.T., Qiu Z.L., Dai S.L., Yi J.H., Li L.F., Zhang Y.F. (2014) Gemological and mineralogical characteristics of nephrite from Ya'an, Sichuan Province. Journal of Gems and Gemmology, Vol. 16, No. 5, pp. 1-8, http://dx.doi.org/10.3969/j.issn.1008214X.2014.05.001 
Leake B.E., Woolley A.R., Arps C.E.S., Birch W.D., Gilbert M.C., Grice J.D., Hawthorne F.C., Kato A., Kisch H.J., Krivovichev V.G., Linthout K., Laird J., Mandarino J.A., Maresch W.V., Nickel E.H., Rock N.M.S., Schumacher J.C., Smith D.C., Stephenson N.C.N., Ungaretti L., Whittaker E.J.W., Youzhi G. (1997) Nomenclature of amphiboles: Report of the Subcommittee on Amphiboles of the International Mineralogical Association Commission on New Minerals and Mineral Names. American Mineralogist, Vol. 82, No. 9/10, pp. 1019-1037, http://dx.doi.org/10.1180/minmag.1997.061.405.13

Leaming S.F. (1998) Jade in Canada: Geological Survey of Canada Papers, Vol. 78, pp. 1-59.

Li X., Yu X.J., Wang S.Q., Mo Y.Y. (2011) The discovery and a preliminary study of Dahua tremolite jade in Guangxi. Acta Petrologica et Mineralogica, Vol. 30, No. Supp., pp. 47-52.

Liu Y., Deng J., Shi G.H., Sun X., Yang L.Q. (2011a) Geochemistry and petrogenesis of placer nephrite from Hetian, Xinjiang, Northwest China. Ore Geology Reviews, Vol. 41, No. 1, pp. 122-132, http://dx.doi.org/10.1016/j.oregeorev.2011.07.004

Liu Y., Deng J., Shi G.H., Yui T.F., Zhang G.B., Abuduwayiti M., Yang L.Q., Sun X. (2011b) Geochemistry and petrology of nephrite from Alamas, Xinjiang, NW China. Journal of Asian Earth Sciences, Vol. 42, No. 3, pp. 440-451, http://dx.doi.org/ $10.1016 /$ i.jseaes.2011.05.012

Liu Y., Zhang R.Q., Zhang Z.Y., Shi G.H., Zhang Q.C., Abuduwayiti M., Liu J.H. (2015) Mineral inclusions and SHRIMP U-Pb dating of zircons from the Alamas nephrite and granodiorite: Implications for the genesis of a magnesian skarn deposit. Lithos, Vol. 212-215, pp. 128-144, http://dx.doi.org/10.1016/ j.lithos.2014.11.002

Lu B.Q. (2005) The Gemological Mineralogy and Spectroscopy of Nephrite Cat's Eye and Serpentine Cat's Eye from Shimian, Sichuan Province, Southwest of China. PhD thesis, Shanghai University, Shanghai.

Marfunin A.S. (1984) Physics of Minerals and Inorganic Materials: An Introduction. Translated by Li G.S, He Y.X., He S.W. Geological Publishing House, Beijing, pp. 149-187.

Mo Z.R., Mao Y.J. (2016) Gemological study of a black jade. Technology Outlook, Vol. 26, No. 21, pp. 258-259, http://dx.doi.org/ $10.3969 /$ j.issn.1672-8289.2016.21.227

National Geological Archives (2013) 1:200000 geologic map of Guangxi and Guizhou Province. http://www.ngac.org.cn/ Document/Map.aspx?MapId=EC7E1A7A782D1954E04301000 07F182E

Peng F., Zhao Q.H., Pei L., Wang C., Yin Z.W. (2017) Study of mineralogical and spectroscopic characteristics of black nephrite from Dahua in Guangxi. Spectroscopy and Spectral Analysis, Vol. 37, No. 7, pp. 2237-2241, http://dx.doi.org/10.3964/ j.issn.1000-0593(2017)07-2237-05

Prokhor S.A. (1991) The genesis of nephrite and emplacement of the nephrite-bearing ultramafic complexes of east Sayan. International Geology Review, Vol. 33, No. 3, pp. 290-300.

Schumacher J.C., Wang L.B. (2001) Estimation of $\mathrm{Fe}^{3+}$ percentage from the electron microprobe data of amphiboles. Acta Petrologica et Mineralogica, Vol. 20, No. 2, pp. 189-198, 207.

Siqin B., Qian R., Zhuo S.J., Gan F.X., Dong M., Hua Y.F. (2012)
Glow discharge mass spectrometry studies on nephrite minerals formed by different metallogenic mechanisms and geological environments. International Journal of Mass Spectrometry, Vol. 309, No. 1, pp. 206-211, http://dx.doi.org/10.1016/j.ijms. 2011.10.003

Tang Y.L., Chen B.Z., Jiang R.H. (1994) Chinese Hetian Nephrite. Xinjiang People's Publishing House, Urumqi, China, pp. 103237.

Wang B., Shao Z.Y., Liao Z.T., Zhou Z.Y. (2012) Gemmological and mineralogical characteristics of nephrite from Guangxi. Journal of Gems and Gemology, Vol. 14, No. 3, pp. 6-11, http://dx.doi.org/10.3969/j.issn.1008-214X.2012.03.003

Wang C.Q., Sun P., Wang. S.Q. (2014) Mineralogical characteristics of Dahua dark nephrite, Guangxi. Acta Petrologica et Mineralogica, Vol. 33, No. S2, pp. 1-9.

Wang C.Y. (1993) Geological and physical, chemical characteristics of Longxi nephrite. Mineral Resources and Geology, Vol 7, No. 35, pp. 201-205.

Wang J.J., Gan Y.H., Li J., Wei J. (2007) Analysis on nephrite conditions and discovery prospects in Dazaohuo area in Qinghai Province. Plateau Earthquake Research, Vol. 19, No. 4, pp. 4751, http://dx.doi.org/10.3969/j.issn.1005-586X.2007.04.008

Wang S.Q., Duan T.Y., Zheng Z.Z. (2002) Mineralogical and petrological characteristics of Xiuyan nephrite and its minerogenetic model. Acta Petrological et Mineralogica, Vol. 21, No. S1, pp. 79-90.

Wen L., Liang W.X., Zhang Z.G., Huang J.C. (1988) The Infrared Spectroscopy of Minerals. Chongqing University Press, Chongqing, China, pp. 85-89.

Wilkins C.J., Tennant W.C., Williamson B.E., McCammon C.A. (2003) Spectroscopic and related evidence on the coloring and constitution of New Zealand jade. American Mineralogist, Vol 88, No. 8-9, pp. 1336-1344, http://dx.doi.org/10.2138/am-2003$8-917$

Yang L. (2013) Study on Petromineral Features and Genetic Mechanism of Luodian Jade, Guizhou Province. Ph.D. thesis Chengdu University of Technology, Chengdu, China.

Yin Z.W., Jiang C., Santosh M., Chen Y.M., Bao Y., Chen Q.L. (2014) Nephrite jade from Guangxi Province, China. Ge G, Vol 50, No. 3, pp. 228-235, http://dx.doi.org/10.5741/GEMS.50.3. 228

Yui T.F., Kwon S.T. (2002) Origin of a dolomite-related jade deposit at Chuncheon, Korea. Economic Geology, Vol. 97, No. 3, pp. 593-601, http://dx.doi.org/10.2113/97.3.593

Yui T.F., Usuki T., Chen C.Y, Ishida A., Sano Y., Suga K., Iizuka Y., Chen C.T. (2014) Dating thin zircon rims by NanoSIMS The Fengtien nephrite (Taiwan) is the youngest jade on Earth. International Geology Review, Vol. 56, No. 16, pp. 1932-1944, http://dx.doi.org/10.1080/00206814.2014.972994

Zhang B.L. (2006) Systematic Gemmology. Geological Publishing House, Beijing, pp. 367.

Zhang X.J., Xiao J.F. (2014) Zircon U-Pb geochronology, Hf isotope and geochemistry study of the Late Permian diabases in the northwest Guangxi Autonomous Region. Bulletin of Mineralogy, Petrology and Geochemistry, Vol. 33, No. 2, pp. 163-176, http://dx.doi.org/10.3969/j.issn.1007-2802.2014.02.003 